\title{
INSTITUTIONS AND OFFSHORING DECISION
}

\author{
MARCELLA NICOLINI
}

CESIFO WORKING PAPER NO. 2074

CATEgORY 7: TRAde Policy

August 2007

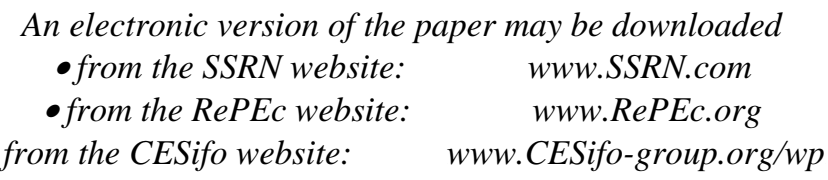




\title{
INSTITUTIONS AND OFFSHORING DECISION
}

\author{
Abstract \\ evidence is weak for products ready for sale. \\ JEL Code: F10, F23. \\ Marcella Nicolini \\ Department of Economics, Business and Statistics \\ University of Milan \\ Via G. Colombo 40 \\ 20100 Milan (MI) \\ Italy \\ marcella.nicolini@unibocconi.it
}

Several papers have proven that the institutional environment of the receiving country can influence the choice to establish an FDI. Property rights theory suggests that contract enforcement matters differentially across sectors. This paper is the first attempt to test whether institutions matter differentially across different sectors in FDI decision. Using data on U.S. Direct Investment Abroad, I find that institutional characteristics of the country and the industry positively affect the volume of offshoring between U.S. companies and their affiliates. The suggested argument is stronger for the intermediate products, while the

First Draft: November, 2006

This Version: July, 2007

I would like to thank Paolo Epifani, Anna Falzoni, Elhanan Helpman and seminar participants at Workshop on International Outsourcing, CESifo, HECER and RUESG (Helsinki 2007) for providing helpful comments. 


\section{Introduction}

The knowledge-capital model of the multinational enterprise incorporates in one framework two types of foreign direct investment. On one side, there is the horizontal type of FDI, which corresponds to the market seeking motivation. Usually, it is to a foreign direct investment in a high-income country, whose market is of interest to the multinational corporation. Multinationals prefer to serve the foreign market with local production, in order to avoid the costs associated with international trade. On the other side, there is the cost reduction motive, which corresponds to the vertical FDI. This type of foreign investment is usually directed to low-income countries, whose markets are less interesting for the multinational enterprise. The aim of this investment is to exploit the comparative advantages of the countries in the production of goods: lower production costs attract part of the production process of multinationals. ${ }^{1}$

Recently, several papers have proven that also the institutional environment of the receiving country can explain FDI inflows. First, a good institutional environment raises productivity, which in turn attracts FDI. Secondly, poor institutions are an additional cost to foreign direct investments, and, finally, a foreign direct investment is vulnerable to uncertainty, due to high sunk costs. All these factors suggest that a good institutional environment in the recipient country is preferred by multinational companies.

The novelty of this paper is that I prove that institutions matter differentially across different sectors. Contracts literature suggests that contract enforcement impacts differentially across sectors, being more important in those sectors that produce more complex goods. Thus, the institutional environment of a country does not impact in the same way on multinationals's decision of offshoring, but it will be more relevant for those sectors that produce more complex goods. These are the sectors that rely more heavily on contract enforcement.

The aim of the present work is to show how institutional quality, and complexity of goods can explain the flows of intra-firm trade between U.S. multinationals and their foreign affiliates. I find, indeed, that institutional characteristics of the country and the industry positively affect trade flows between U.S. companies and their affiliates. In the analysis, I exploit several measures of intra-firm trade flows. First, I consider the sum of total intra-firm trade flows, running in both directions. Then, I employ separately trade flows from

\footnotetext{
${ }^{1}$ For an overview on multinationals and foreign direct investments, see Barba Navaretti and Venables (2004).
} 
U.S. parent companies to foreign affiliates, and vice versa. Finally, I exploit the difference between good shipped for simple resale in the foreign market, and goods shipped for further manufacturing. I show that the suggested argument is stronger for the intermediate products, while the evidence is weak for those products ready for sale. This confirms that the contractual determinants of trade are not at work in the case of final goods.

The remainder of the paper is structured as follows. Section 2 reviews the literature on contacts and international fragmentation of production. Section 3

outlines the empirical model, Section 4 presents the data. Section 5 deals some econometric issues and presents the results. Finally, Section 6 concludes.

\section{Institutional Quality, Contracts and Offshoring}

Several papers have underlined how the choice of starting a foreign direct investment can depend also on the quality of the institutions of the receiving country. Wei (2000) finds that inward flows of foreign direct investments are reduced by high levels of corruption in the recipient country. Globerman and Shapiro (2002, 2003) suggest that institutional quality has a positive impact both on inward and outward FDI, while Aizenman and Spiegel (2002) demonstrate that the share of FDI is decreasing in corruption levels.

Bénassy-Quéré, Coupet and Mayer (2007) estimate a gravity equation for bilateral FDI stocks that includes institutional quality measures for the two countries, and find that the measures of institutional quality are both positive and significant. Alfaro, Kalemli-Ozcan and Volosovych (2005) find that institutional quality, as instrumented by its historical determinants, is an important determinant of capital flows, defined as FDI plus portfolio equity. Using a data set that covers the period 1970-2000, they demonstrate that the Lucas' paradox (1990) may be explained by differences in institutional quality. The institutional environment explains also capital volatility: lower levels of institutional quality implies higher capital volatility.

The Grossman-Hart-Moore model has given inspiration to a number of paper in international trade literature, which have been focusing on the boundaries of the firm, and the choice between outsourcing and internalization. McLaren (2000) considers the choice made by the final good producer and the input supplier located in the same country, between arm's-length production and integrated procurement. In equilibrium, thickness of the market favours outsourc- 
ing. Grossman and Helpman (2002) model the choice between integration and outsourcing, in a closed economy framework. The mode of organization is determined in equilibrium by the trade off between the costs of running a larger and less specialized organization and the costs of imperfect contracting and search frictions. Grossman and Helpman (2005) present a monopolistic competition model in which firms outsource part of their production, and choose between outsourcing at home or abroad. They show that an improvement of contract enforcement in a country raises the relative profitability of outsourcing there. In another paper (2003), they consider firms that acquire their inputs from another country, where production is cheaper. The authors neglect the determination of the location of component production, and focus on the choice between outsourcing and FDI. The firms choose in this model between outsourcing in the foreign country and foreign direct investment. This choice depends on industry size, contracting environment and relative wages. Ottaviano and Turrini (2003) consider the choice of the multinational to serve a foreign market with exports or foreign direct investment. If FDI is chosen, the firm chooses also between self-production and outsourcing of intermediate inputs. Their model predicts non linearities between FDI and trade costs: foreign direct investments may emerge with both low and high trade costs. Ornelas and Turner (2005) consider the firm's choice between a standardized intermediate input produced at home, or a customized input produced abroad. They focus on the effect of a trade liberalization in a model with contact incompleteness, and show that it may prompt vertical integration.

All these models assume that hold up occurs only between the supplier of the intermediate input and the final producer. Antràs instead follows the works of Grossman, Hart and Moore $(1986,1990)$ and allows for the possibility of hold up also within firm boundaries. In his model (2003) he builds a property-rights model of the boundaries of the firm. He predicts that costs of outsourcing are increasing in the capital intensity of the imported good, thus, capital-intensive goods will be produced within the firm. He provides empirical evidence that U.S. intra-firm trade takes place mostly in capital-intensive sectors, with capital abundant countries. Antràs and Helpman (2004) combine the within sectorial heterogeneity modelled by Melitz (2003) with the model of the firm boundaries developed by Antràs (2003) and focus on the choice between integration or arm's length relationship for the production of intermediate inputs, both at home and abroad. The firm faces two different decisions: the first is whether to produce a component at home, or in foreign country. The second is whether 
to produce within firm boundaries, or outside it, with an arm's length contract. According to productivity and sectorial characteristics, four different organizational forms exist in equilibrium. This model endogenizes both outsourcing and location decision. In a subsequent paper (2006), they allow for varying degrees of contractibility across inputs and countries, adopting the incomplete contracts formulation developed in Acemoglu, Antràs, Helpman (2007). They find that an increase in the contractibility of inputs has different effects, depending on the country in which it takes place: an improvement in institutions in the finalgood producer's country encourages outsourcing, while an improvement in the institutions of the supplier's country encourages integration.

Few empirical works exist in this stream of literature, mainly due to data limitations. Feenstra and Hanson (2005) look at processing imports and exports in China, with data at HS 8-digits level. They possess information on the ownership structure, and find that the allocation of ownership and control is generally shared between foreign and local parties. Swenson (2005) focuses on the determinants of outsourcing abroad. Using data on the offshore assembly program (OAP) of the Unites States, she shows that outsourcing activity is responsive to country's costs and industry characteristics. Using a rich data set on U.S. firms, Bernard, Jensen and Schott (2005) show that multinationals have a constant breakdown of trade between intra-firm and arms' length transaction, which equally cover the trade flows of multinationals. Moreover, also the share of exclusively arm's-length exporters or importers has remained substantially stable over the period considered. ${ }^{2}$ Using the same database, Nunn and Trefler (2007) test empirically the predictions of Antràs (2003) and Antràs Helpman (2004, 2006). Their test of Antràs Helpman (2006) is closest in spirit to the subsequent analysis, although they control if the relative prevalence of vertical integration over outsourcing depends on industries contractibility, countries institutional quality and headquarter intensity. Given their focus on the model, they neglect in their analysis controls for the standard determinants of offshoring, and they do not exploit the information on the intended use of the shipped good.

\footnotetext{
${ }^{2}$ Their newly created data set has also firm level information on the amount of goods exchanged through arm's length relationships.
} 


\section{The Empirical Model}

A huge bulk of theoretical literature has shown how contractual imperfections determine the choice of the firm between production in house or subcontracting, either at home or abroad. I do not inspect the determinants of these choices, instead I focus on multinationals and the organization of production within them. Multinational enterprises split the production process between parent company and affiliates located in other countries. The focus of the analysis is the offshoring of production. I consider only those goods whose production takes place entirely within multinational boundaries, although in different countries. Thus, production has been offshored, but not outsourced. Of course, part of the production may have been outsourced too, unfortunately, I do not possess any information on the entity of the outsourcing activity implemented. Therefore, I limit my analysis to the flows of goods that are produced in house. I analyse the impact that institutions have on the organization of production within multinational firm boundaries.

The hypothesis that I want to test is that institutional quality of the country of the affiliate affects the production choice of the multinational firm. Following the Grossman-Hart-Moore framework, and, more recently, Antràs (2003), I suppose that hold-up concerns exist also within an integrated firm. As the risk of hold-up is present, I expect that the fragmentation of production will be favoured in countries that present a better contract enforcement. Therefore, institutional quality matters for organization of production within firm boundaries, with better contract enforcement in the affiliate country favouring offshoring within firm boundaries. ${ }^{3}$

Acemoglu, Antràs, Helpman (2007), Costinot (2005), Levchenko (2007) and Nunn (2007) have shown that a poor contracting environment impacts differentially across sectors, being more detrimental to sectors that produce more complex goods. In other words, a good enforcement of contracts is a source of comparative advantage in the production of those goods that require a large number of intermediate inputs, and consequently a large number of contracts with several input suppliers, in order to be produced.

Given the choice of the firm to produce abroad through an FDI, I expect that good contract enforcement in the host country favours offshoring of pro-

\footnotetext{
${ }^{3}$ This is close to Antràs Helpman (2006) prediction that an improvement in the contractibility of an input provided by a foreign supplier encourages integration in face of offshore outsourcing.
} 
duction in more contract-dependent sectors. More institutionally dependent goods will be produced preferentially with affiliates located in countries with good institutional quality.

Of course, testing the institutions hypothesis, I have to control for the standard determinants of offshoring of production. Two different reasons may motivate foreign direct investments. The first is the market access motive, which corresponds to the horizontal type of foreign direct investment. The second is the cost reduction motive, that pushes multinationals to fragment their production in order to reap cost gains, which corresponds to the vertical FDI framework. The knowledge capital model shows that these two forms can coexist. Hanson, Mataloni and Slaughter (2001) provide empirical evidence that nowadays multinationals' expansion strategies have both vertical and horizontal features. Accordingly, I have to consider both types of determinants together.

The horizontal motive can be tested with country characteristics, industry characteristics and trade costs measures. In order to test the vertical motive, I have to consider that costs vary across countries and industries according to comparative advantage. I enrich the standard test of the vertical FDI, considering institutional quality as an additional source of comparative advantage in the production of complex goods. This is a safe assumption, as several authors ${ }^{4}$ have already demonstrated that institutional quality can be a source of comparative advantage in the production of more complex goods, which require a large number of contracts in order to be produced. The aim of the empirical analysis is thus to test whether the institutional comparative advantage matters in multinational choices of production.

I estimate the following equation:

$$
\text { flow }_{i c t}=\alpha+\text { inst }_{i c t}+\text { hor }_{i c t}+\text { ver }_{i c t}+\varepsilon_{i c t}
$$

where $i$ is the sector, $c$ the country and $t$ the time period. hor $r_{i c t}$ corresponds to a set of variables that determine the choice to establish an horizontal direct investment abroad, $v e r_{i c t}$ is a set of measures of production costs, which vary across countries and sectors and inst $_{i c t}$ is a measure of the institutional quality driven comparative advantage. I use intra-firm trade flows as a measure of the offshoring activity by multinationals.

\footnotetext{
${ }^{4}$ Costinot (2005), Levchenko (2007), Nunn (2007), Acemoglu Antràs Helpman (2007).
} 


\section{The Data}

The data used in the analysis come from the data set on U.S. Direct Investment Abroad, maintained by the Bureau of Economic Analysis (BEA), U.S. Department of Commerce. I employ different measures of sales between nonbank U.S. multinationals and theirs majority-owned nonbank affiliates. These are enterprises in which the U.S. entity has at least a $51 \%$ equity stake. I use data from the benchmark surveys in years 1994 and 1999. Although data on direct investment abroad are available for every year, only benchmark surveys contain the information on the intended use of the good traded, namely the choice between further manufacturing or resale. ${ }^{5}$

As dependent variable I consider in turn several measures on intra-firm trade flows. First, I use the value of total intra-firm trade, which I obtain summing trade flows running in both directions. Then, I inspect separately trade flows of goods from foreign affiliates to parent companies ${ }^{6}$ and trade flows from U.S. parents to foreign affiliates. Finally, I exploit the distinction between goods shipped for further manufacturing and good shipped for resale. Unfortunately, this information is available only for trade flows to foreign affiliates. ${ }^{7}$

Institutional dependence at industry level, inst ${ }_{i}$, is measured with Nunn's (2007) measure of contract intensity. ${ }^{8}$ In the robustness section, I show that the results hold also using Herfindahl index as proxy for product complexity. ${ }^{9}$ I compute these indicators using the U.S. Input-Output Table for $1992^{10}$ and for 1999. I am assuming that the existing structure of intermediate inputs use in the United States is driven by technology differences across sectors, and that these technological differences carry over to the other countries.

Measures of institutional quality, inst ${ }_{c}$, are taken from the Governance Matters IV Database (Kaufmann et al. 2005). This data set, maintained by the World Bank, provides six different indexes of institutional quality, that range from -2.5 (poor quality) to 2.5 (good quality $)^{11}$. These indicators focus on different aspects of institutional quality: Voice and Accountability, Political Instability and Violence, Government Effectiveness, Regulatory Burden, Rule of Law, which refers specifically to the level of contract enforcement, and Con-

\footnotetext{
${ }^{5}$ See Appendix A.1 for further information on data issues.

${ }^{6}$ This measure has been employed also in Yeaple (2003).

${ }^{7}$ Another attempt to exploit the information on the intended use is Yeaple (2006).

${ }^{8}$ See Appendix A.2 for more details on how the measure is constructed.

${ }^{9}$ This measure has been employed by Levchenko (2007).

${ }^{10}$ US Input-Output table for 1994 is not available.

${ }^{11}$ These indexes have mean zero and a standard deviation of 1 .
} 
trol of Corruption. These measures are based on a large number of individual variables, which measure the perceptions of governance. Also these measures are normalized between 0 and 1, with larger values corresponding to better institutional quality. For a description of the variables, see Appendix A.3 Table 1 shows the correlations between different measures of institutional quality at country level. All correlations are positive and significant at $1 \%$ level. Then, multiplying inst $_{c}$ and inst $_{i}$, I obtain a measure of institutional dependence that is country and industry specific.

I assume that there are no factor intensity reversals, thus implying that factor shares are fixed for each industry across countries. Therefore, factor intensities can be ranked using factor share data for just one country. I use U.S. industry data for reasons of availability, moreover they are the most satisfactory, as the United States are the largest and most diverse industrial economy. Data for factor intensities come from the U.S. Manufacturing database maintained by NBER and U.S. Census Bureau's Center for Economic Studies for 1994 and $1996 .{ }^{12}$ capital $_{i}$ is a measure of capital intensity, and is equal to one minus the share of total compensation in value added. skill $_{i}$ is a measure of skilled labour intensity, and is equal to the ratio of non production workers to total employment, multiplied by the total share of labour in value added.

I test the relevance of comparative advantage in intra-firm flows by an interaction of factor intensities and relative factor prices. ${ }^{13}$ To determine relative factor prices I use relative factor abundance, taken from Hall and Jones (1999).

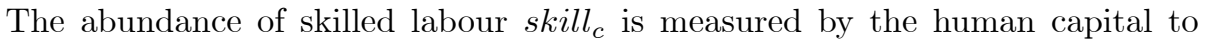
labor ratio, which is based on the education levels reported in Barro and Lee (2000). The abundance of capital capital $_{c}$ is measured by the investment based measure of the capital to labor ratio, sourced from Hall and Jones (1999).

I add a set of variables to control for the classical determinants of FDI. In order to control for the horizontal motive for foreign direct investment, I include a measure of market size, namely the log of GDP in current U.S. dollars, taken from the World Development Indicators. The measures for tariffs are taken from the CEPII tariffs data set. Tariffs are measured at the bilateral industry-level in percentages. NTBs are classified following Haveman's (2003) treatment of TRAINS. I include a measure of transport cost, (freight plus insurance) taken from the Feenstra World Trade Flows Dataset. I add some measures of scale, in order to test the horizontal FDI hypothesis. I build a measure of plant level

\footnotetext{
${ }^{12}$ Data for 1999 are not available, I used data for 1996 as it is the most recent year available.

${ }^{13}$ This choice reflects the test of comparative advantages developed by Romalis (2004).
} 
scale economies as the number of production workers per establishment. It is the average size of a plant in the U.S. by industry, that gives a measure of plant-level fixed costs. The variable corp.scale is a measure of corporate scale economies, and is the average number of non production workers per company. ${ }^{14}$ Finally, I control for fiscal regime in the foreign country, using several proxies taken from the World Development Indicators. Following the literature, I consider the highest marginal corporate tax rate, which is the highest rate shown on the schedule of tax rates applied to the taxable income of corporations. ${ }^{15}$

\section{Econometric Analysis}

\subsection{The Choice of Estimation Technique}

The dependent variable, flow $_{i c t}$, assumes only positive values and is not continuous, moreover it presents a large number of zero observations. Using ShapiroFrancia test for normality, I find that all different measures of trade flows are not normally distributed, nor are their logarithmic transformations. Given the distribution of my dependent variable, I may refer to the family of count data models. Several reasons suggest that this could be the optimal choice. First, the dependent variable is integer, and does not have a continuous distribution. Moreover, Santos Silva and Tenreyro (2005) suggest that the widely adopted log-linearization of the dependent variable, estimated by OLS, produces inconsistent estimates in presence of heteroskedasticity.

Among count data models, Poisson regression model ${ }^{16}$ is the first choice. Poisson distribution requires that mean and variance assume the same value for the dependent variable. This is often difficult to find in the data, therefore in this cases the solution is to move to the negative binomial regression model, that allows mean and variance to differ. Alternatively, another way to treat overdispersion is to consider models that take into account the overrepresentation of zeros in the sample: these are the zero inflated Poisson model and the zero inflated negative binomial model.

A quick look at summary statistics of the different dependent variables considered in the analysis is presented in Table 2 . It shows that all these different measures of trade flows present overdispersion. Figure 1 shows the plot of the

\footnotetext{
${ }^{14}$ Data come from the 1992 Census of Manufacturers and 1997 Manifacturing Economic Census.

${ }^{15}$ Results are robust also controlling for the role of value added tax.

${ }^{16}$ This is a common choice when using this data set on intra-firm trade, see Yeaple (2006).
} 
probabilities observed, and the probabilities predicted by the different models considered. ${ }^{17}$ The graph shows that Poisson model is unable to predict correctly the observed distribution. The other distributions seem to fit better our data, especially negative binomial regression and zero inflated negative binomial regression. This qualitative analysis suggests the use of a negative binomial or a zero inflated negative binomial regressor. Among these, Long and Freese (2005) suggest that negative binomial is to be preferred as it is simpler. ${ }^{18}$

In order to choose, I estimate the simplest equation of interest using different estimation techniques, then I perform a number of test in order to choose the correct estimator. Table 3 shows the results of the regression of the total intrafirm flows on the interacted term between institutional quality at country level, and institutional dependence at industry level. First, I observe that the coefficient of interest is always positive and significant, across different regressions. Moreover, the magnitude of the coefficient is rather stable. In order to compare these non-nested model, I look at the Bayesian Information Criterion. It would suggest that the Negative Binomial Regression is the one that captures better the nature of the data. This confirms the qualitative analysis of the distributions represented in Figure 1, in which negative binomial and zero-inflated negative binomial seem the two specifications to be preferred. I obtain analogous results observing the Akaike's information criteria.

To properly determine the correct regressor, I perform a number of tests. A goodness-of-fit test for the Poisson specification is implemented: the statistic rejects the hypothesis that data are Poisson distributed. A Vuong test of ZIP versus standard Poisson gives a positive and significant statistic, thus favouring the ZIP model. Although ZIP does not seem to perform well looking at BIC statistics, it is nevertheless to be preferred to the standard Poisson estimator. The reason is that including the zero inflation process is a way to take into account the overdispersion present in the data. Anyway, as overdispersion is a problem in the data, negative binomial is to be preferred. The likelihood ratio test of $\alpha$, the overdispersion parameter, equal to zero strongly rejects the null hypothesis: thus, I can affirm that overdispersion is present in the data, and negative binomial distribution better fits the data. Finally, a Vuong test of ZINB versus NB suggests that NB is to be preferred.

\footnotetext{
${ }^{17}$ Figure 1 shows the observed and predicted probabilities for total intra-firm trade flows. The analysis with the other measures of intra-firm trade provides similar results, therefore the other figures are not reported.

${ }^{18}$ See Long and Freese (2005) p. 260.
} 
The last column of Table 3 presents the same model, estimated using OLS. The dependent variable in this specification is $\log \left(\right.$ flow $\left._{i c t}+1\right)$. The coefficient estimate is close to the ones predicted using the other estimators. Nevertheless, the Breusch-Pagan test rejects the null hypothesis of homoskedasticity. ${ }^{19}$ Monte Carlo simulations performed by Santos Silva and Tenreyro (2005) show that estimates using log-linearized models are severely biased in presence of heteroskedasticity. Therefore, the log-linearized model is not a suitable choice, and the negative binomial regression will be employed in the following analysis.

\subsection{Results}

I start the empirical analysis using as dependent variable total intra-firm trade flows running in both directions, from parent companies to foreign affiliates and vice versa. Table 4 shows the results. In addition to the interacted term between institutional quality at country level and institutional dependence at industry level alone, I control for the impact of the two variables alone. The amount of trade flows between parent companies and foreign affiliates can be affected by the size of the parent company. One could expect that larger industries present larger flows of intra-firm trade. Therefore, I control for the parent company size, measured by total sales by parent companies included in the BEA data set.

Column (1) in table 4 shows that the institutional variable has a positive and significant coefficient, as expected. Thus, intra-firm trade flows are positively affected by good levels of contract enforcement, especially in contract-intensive industries. As expected, the coefficient attached to the sales variable is positive and significant. I control for market size, in order to test for the horizontal type of FDI. I observe a positive and significant coefficient, that confirms the presence of a market seeking motive. Column (2) adds a number of controls for vertical determinants of foreign direct investment. The measure of plant scale economies has a negative and significant coefficient. This confirms the idea that opening a new plant is unfavourable in presence of plant scale economies. Instead, the corporate scale variable has a positive and significant coefficient, suggesting that there is an incentive to the opening of subsidiaries in case of this scale economies. I control for the role of the corporate tax rate. The estimated coefficient is not significant. Tariffs have a negative and significant impact, as expected, while non-tariff barriers to trade, proxied by a measure of their coverage, show a coefficient estimate that is not statistically different from

\footnotetext{
${ }^{19} \mathrm{I}$ also plot the residuals versus fitted values, observing a pattern between the two.
} 
zero. Freight and insurance costs have a negative and significant coefficient. Also Hanson, Mataloni and Slaughter (2005) find that higher trade costs reduce the demand for intermediate inputs shipped by U.S. parent companies to their foreign affiliates.

In columns (3) and (4) I include classical determinants of comparative advantage. The coefficient estimate for the institutional variable remains positive and significant. Finally, column (6) includes both controls for vertical and horizontal determinants of foreign direct investment. The coefficient of interest remains positive and significant. Table 4 reports the test for the hypothesis that the overdispersion parameter, $\alpha$, is equal to zero. The likelihood ratio test always rejects the null hypothesis, thus showing again that the estimator to be employed has to take into account overdispersion.

I decompose the total measure of intra-firm trade flows into its two components: trade flows from the parent company toward foreign affiliates, and flows of goods from the affiliate to the U.S. parent company.

Looking at trade flows running from affiliates to parent companies, I observe that the institutional variable is generally positive albeit not significant across different specifications presented in table 5 . Control variables have the expected coefficients, and are generally significant.

Considering in turn trade flows from U.S. companies to foreign affiliates, I obtain again a positive and significant coefficient for the institutional variable. Control variables for horizontal FDI always present a positive and significant coefficient. Table 6 shows the results.

Comparing the log likelihood across different sets of estimates, I observe that splitting the dependent variable into its two components improves the fit of the estimates: log likelihood is always larger in absolute terms in estimates presented in table 4, in comparison with results shown in tables 5 and 6 .

I can decompose further my dependent variable. Trade flows from the U.S. to foreign affiliates can be disentangled into flows of goods shipped for further manufacturing, and flows of goods shipped to foreign affiliates for resale. I look first at trade flows of goods shipped for further manufacturing. I observe again that the coefficient attached to the institutional variable is positive and significant across the different specifications. This is an additional confirmation of my hypothesis. I find that the choice of the multinational firm in the fragmentation of the production process is influenced by the comparative advantage given by the good contract enforcement of the country in which the affiliate is located. Of course, other country or industry characteristics may influence this choice. 
These have been controlled for in the alternative specifications presented in table 7.

If I consider, finally, the flows of goods shipped for resale, I observe that the coefficient for $i_{n s t} *$ inst $_{c}$ is generally not significant. Apart from market size, also the other control variables generally show a coefficient estimate that is not significant. These results confirm the intuition that the contractual determinant of offshoring is not at work when considering goods that do not need further manufacturing or, in other terms, final goods.

In order to assess the relevance of the institutional variable across different sets of estimates, I compute the marginal effects. Table 9 presents marginal effects for the institutional variable across different specifications. The first line shows the marginal effect when the dependent variable in the equation is the amount of goods shipped from U.S. companies to foreign affiliates. The other two lines present the marginal effects computed when the dependent variable is the flow of goods shipped for further manufacturing, and the flow of goods shipped for resale.

The marginal effects are larger that the estimated coefficients when considering trade flows to foreign affiliates, and goods shipped for further manufacturing. Looking at the marginal effects for the regressions on the goods for resale, I observe that they are much smaller is size that the coefficient estimates, moreover they are never significant. Thus, I can affirm that the institutional variable impacts on the choice of splitting the production between two countries, but has a negligible impact when considering intra-firm trade flows of final goods. ${ }^{20}$

\subsection{Robustness and Sensitivity Analysis}

So far I have not inspected the time-varying dimension of my dataset. All previous estimates pool together observations from two different time periods. As Greene (2001) suggests, given the short time period, one could simply add time dummies to the model. Therefore, I reestimate the previous equations adding a time dummy. Results do not change. ${ }^{21}$ Table 10 shows that the inclusion of a set of country dummies, industry dummies or both does not change the result that intra-firm trade is increasing in country's institutional quality and sector's institutional dependence. It suggests also that it is important to take into account these effects.

\footnotetext{
${ }^{20}$ The marginal effect is actually never statistically different from zero.

${ }^{21}$ These estimates are not reported, but are available upon request.
} 
Thus, I move to panel estimates. My data vary over three dimensions: country, sector and time. I choose as dimensions of my panel countries and time. As regards the choice between fixed or random effects, I would a priori choose fixed effects, as I could expect country or sector effects to be correlated with the other regressors. Unfortunately, fixed effects estimator has a number of shortcomings. It is not possible to obtain coefficient estimates for time-invariant regressors, ${ }^{22}$ as they are absorbed by the fixed effects. Groups in which trade flow does not change in time are dropped: given the short time span, only two years, this is likely to occur. ${ }^{23}$ As my panel is unbalanced, all the group with only one observation are dropped with fixed effects, but not with random effects. Finally, Greene (2001) notes that as individual effects are estimated with $T(i)$ observations, a short time period implies a small sample bias and inconsistent estimates for the effects.

In order to choose between fixed and random effects, I consider a baseline specification using different dependent variables, and perform a Hausman test. Table 11 shows that coefficient estimates are very close between fixed and random effects. Hausman test does not reject the null hypothesis of absence of correlation between individual effects and the other regressors, thus suggesting that the effects should be considered as random.

Table 12 reports the baseline specification using different dependent variables. These results confirm the finding that the institutional variable has a positive impact on intra-firm trade flows. The coefficient of interest is positive and significant, both considering trade to foreign affiliates, and trade of goods for further manufacturing. Instead, trade of goods for resale seems not affected by the institutional quality variable: the coefficient is now statistically not different from zero.

As a further robustenss check, I perform the panel estimates considering sectors as my group variable. Table 13 shows that the results are not affected: the institutional variable displays a positive and significant coefficient.

Finally, I perform some sensitivity analysis. As all the analysis focuses on the role of the institutional variable, I control re-estimating with alternative measures of institutional quality at country, and industry level. The main concern lies in the measure of institutional intensity at industry level. Indeed, as

\footnotetext{
${ }^{22}$ In my dataset, capital and skilled labour endowments are time invariant.

${ }^{23}$ Consider a country in which no FDI, and therefore no intra-firm trade, was present in 1994. If no multinational start an FDI in the following five years, I will observe again an absence of trade flow for this country. In the panel fixed effect estimate, these two observations would be dropped.
} 
regards institutional quality at country level, a number of valuable alternatives are made available by the World Bank, in the Governance Matters Database. Results with these alternative measures are robust. ${ }^{24}$

Institutional intensity at industry level is a rather vague concept, hardly measurable. Presently, the most acknowledged measure is the one defined by Nunn (2007). Nonetheless the use of measures of concentration, like Herfindahl index, as an indicator of product complexity is also recognized in literature. ${ }^{25}$ Table 14 reports the results obtained with Herfindahl index. Results do not change, suggesting that the previous analysis is robust, and does not depend on the specific proxy adopted to measure institutional intensity.

Instead of limiting my analysis to standard measures used in literature, I develop a number of alternative measures of concentration of intermediate input use: entropy, normalized entropy, exponential index, Herfindahl index, normalized Herfindahl index, Gini coefficient, concentration coefficient, share of top 10, 20 and 30 intermediate inputs in total intermediate good expenditure. I use also the number of intermediates employed in the production. This is a rawer measure of complexity of an industry, as it gives the same weight to large and insignificant inputs, ignoring differences in the entity of various inputs. ${ }^{26}$ Results are robust also when employing these alternative measures.

\section{Conclusions}

Classical determinants of foreign direct investments are the market access motive, and the cost reduction motive. On one side, the market seeking motivation corresponds to the horizontal type of FDI. Usually, this corresponds to a FDI in a developed economy, whose market is of interest to the multinational corporation, which prefers to serve it with local production, in order to avoid the costs associated with international trade. On the other side the cost reduction motive correspond to the vertical FDI. This type of foreign investment is usually directed to developing countries, whose market is less interesting for the multinational enterprise. The aim of this investment is to exploit the comparative advantages of the countries in the production of goods. Thus, usually these investments are located in developing countries with low labour costs.

Recently, several papers have proven that also the institutional environment

\footnotetext{
${ }^{24}$ Results are available upon request.

${ }^{25}$ See Blanchard Kremer (1997), Cowan Neut (2007) and Levchenko (2007).

${ }^{26}$ See Appendix A.2 for further details on how these variables are constructed.
} 
of the receiving country can influence the choice to establish an FDI in a foreign country. Past literature has always considered institutional quality at country level. The property rights theory suggests that contract enforcement matters differentially across sectors, being more important for sectors that produce more complex goods. This paper is the first attempt to test whether institutions matter differentially across different sectors in FDI decision.

Using data on U.S. Direct Investment Abroad, I find that institutional characteristics of the country and the industry positively affect the volume of offshoring that takes place between U.S. companies and their affiliates. I first consider total intra-firm trade flows, in both directions. Then I consider separately trade flows from U.S. parent companies to foreign affiliates, and vice versa. Finally, I exploit the difference between good shipped for simple resale in the foreign market, and goods shipped for further manufacturing. I show that the suggested argument is strong for the intermediate products, while the evidence is weak for those products ready for sale. This confirms that the contractual

determinants of trade are not at work for these goods, whose production has not been split between parent company and foreign affiliate.

\section{References}

[1] Acemoglu, Daron, Pol Antràs and Elhanan Helpman, 2006, "Contracts and Technology Adoption", American Economic Review, 97(3): 916-943

[2] Aizenman, Joshua and Mark M. Spiegel, 2002, "Institutional Efficiency, Monitoring costs, and the Investment share of FDI", NBER working paper No. 9324

[3] Alfaro, Laura, Areendam Chanda, Sebnem Kalemli-Ozcan and Selin Sayek, 2004, "FDI and Economic Growth: the Role of Local Financial Markets", Journal of International Economics, 64(1): 89-112

[4] Alfaro, Laura, Sebnem Kalemli-Ozcan and Vadym Volosovych, 2005, "Capital Flows in a Globalized World: the Role of Policies and Institutions", NBER Working Paper No. 11696

[5] Antràs, Pol, 2003, "Firms, Contracts, and Trade Structure", The Quarterly Journal of Economics, 118(4): 1375-1418 
[6] Antràs, Pol and Elhanan Helpman, 2004, "Global Sourcing", Journal of Political Economy, 112(3): 552-580

[7] Antràs, Pol and Elhanan Helpman, 2006, "Contractual Frictions and Global Sourcing", NBER working paper No. 12747

[8] Baltagi, Badi H., 2001, A Companion to Theoretical Econometrics, Blackwell Publishers

[9] Barba Navaretti, Giorgio and Anthony J. Venables, 2004, Multinational Firms in the World Economy, Princeton University Press, Princeton and Oxford

[10] Barro, Robert J. and Jongwha Lee, 2000, "International Data on Educational Attainment, Updates and Implications", NBER Working Paper No. 7911

[11] Bartelsman, Eric J. and Wayne Gray, 1996, "The NBER Manufacturing Productivity Database", NBER Technical Working Paper No. 205

[12] Bénassy-Quéré, Agnès, Maylis Coupet and Thierry Mayer, 2005, "Institutional Determinants of Foreign Direct Investment", The World Economy, 30(5): 764-782

[13] Bernard Andrew B., J. Bradford Jensen and Peter K. Schott, 2005, "Importers, Exporters and Multinationals: A Portrait of Firms in the U.S. that Trade Goods", CES Discussion Papers 05-20

[14] Blanchard, Oliver and Michael Kremer, 1997, "Disorganization", Quarterly Journal of Economics, 112: 1091-1126

[15] Cameron, Colin A. and Pravin K. Trivedi, 1998, Regression Analysis of Count Data, Cambridge University Press

[16] Costinot, Arnaud, 2005, "Contract Enforcement, Division of Labor, and the Pattern of Trade", mimeo

[17] Cowan, Kevin and Alejandro Neut, 2007, "Intermediate Goods, Institutions and Output Per Worker", Central Bank of Chile, Working Papers No. 420

[18] Feenstra, Robert C. and Gordon H. Hanson, 2005, "Ownership and Control in Outsourcing to China: Estimating the Property Rights Theory of the Firm", The Quarterly Journal of Economics, 120(2): 729-762 
[19] Feenstra, Robert C., Robert E. Lipsey, Haiyan Deng, Alyson C. Ma, Hengyong Mo, 2005, "World Trade Flows: 1962-2000", NBER Working Paper No: 11040

[20] Globerman, Steven and Daniel M. Shapiro, 2002, "Global Foreign Direct Investment Flows: The Role of Governance Infrastructure", World Development, 30(11): 1899-1919.

[21] Globerman, Steven and Daniel M. Shapiro, 2003, "Governance Infrastructure and U.S. Foreign Direct Investment", Journal of International Business Studies, 34: 19-39

[22] Greene, William H., 2001, "Fixed and Random Effects in Nonlinear Models", mimeo, New York University

[23] Grossman, Sanford, and Oliver Hart, 1986, "The Costs and Benefits of Ownership: A Theory of Vertical and Lateral Integration", Journal of Political Economy, 94: 691-719

[24] Grossman, Gene M. and Elhanan Helpman, 2002, "Integration versus outsourcing in industry equilibrium", The Quarterly Journal of Economics, 117: $85-120$

[25] Grossman, Gene M. and Elhanan Helpman, 2003, "Outsourcing versus FDI in Industry Equilibrium", Journal of the European Economic Association, 1: $317-327$

[26] Grossman, Gene M. and Elhanan Helpman, 2005, "Outsourcing in a Global Economy", Review of Economics Studies, 72: 135-159

[27] Habib, Mohsin and Leon Zurawicki, 2002, "Corruption and Foreign Direct Investment", Journal of International Business Studies, 33(2): 291-307

[28] Hall, Robert, and Chad Jones, 1999, "Why Do Some Countries Produce So Much More Output per Worker than Others", The Quarterly Journal of Economics, 114: 83-116

[29] Hanson, Gordon H., Raymond J. Mataloni and Matthew J. Slaughter, 2001, "Expansion Strategies of U.S. Multinational Firms", NBER Working Paper No. 8433 
[30] Hanson, Gordon H., Raymond J. Mataloni and Matthew J. Slaughter, 2005, "Vertical Production Networks in Multinational Firms", The Review of Economics and Statistics, 87(4): 664-678

[31] Hart, Oliver and John Moore, 1990, "Property Rights and the Nature of the Firm", Journal of Political Economy, 98: 1119-1158

[32] Hausman, Jerry, Bronwyn H. Hall and Zvi Gliliches, 1984, "Econometric Models for Count Data with an Application to the Patents-R \& D Relationship", Econometrica, 52(4): 909-938

[33] Haveman, Jon D., 2003, "Foreign Tariff Reductions and California Exports" Public Policy Institute of California, San Francisco, California,

[34] Helpman, Elhanan, 2006, "Trade, FDI, and the Organization of Firms", NBER Working Paper No. 12091

[35] Helpman, Elhanan, and Paul R. Krugman, 1985, Market Structure and Foreign Trade, MIT Press, Cambridge, MA

[36] Heston, Alan, Robert Summers and Bettina Aten, 2002, Penn World Table Version 6.1, Center for International Comparisons at the University of Pennsylvania (CICUP).

[37] Kaufmann, Daniel, Aart Kraay and Massimo Mastruzzi, 2005, "Governance Matters IV: Governance Indicators for 1996-2004", mimeo, World Bank

[38] Levchenko, Andrei, 2007, "Institutional Quality and International Trade." Review of Economic Studies, 74(3): 791-819

[39] Long, J. Scott and Jeremy Freese, 2005, Regression Models for Categorical Dependent Variables using Stata, Stata Press Publication, College station, Texas

[40] Lucas, Robert E. Jr., 1990, "Why Doesn't Capital Flow from Rich to Poor Countries?", The American Economic Review, Papers and Proceedings 80(2): $92-96$

[41] Markusen, James R., 2002, Multinational Firms and the Theory of International Trade, The MIT Press, Cambridge, MA

[42] Mataloni, Raymond J., 1995, "A Guide to BEA Statistics on U.S. Multinational Companies", Survey of Current Business 75: 38-55 
[43] McLaren John, 2000, " "Globalization" and Vertical Structure", The American Economic Review, 90(5): 1239-1254

[44] Melitz, Marc J., 2003, "The Impact of Trade on Intra-Industry Reallocations and Aggregate Industry Productivity", Econometrica, 71(6): 16951725

[45] North, Douglass C., 1990, Institutions, Institutional Change and Economic Performance, Cambridge University Press

[46] North, Douglass C., 1991, "Institutions", Journal of Economic Perspectives, 5(1): 97-112

[47] Nunn, Nathan, 2007, "Relationship-Specificity, Incomplete Contracts, and the Pattern of Trade", Quarterly Journal of Economics, 122(2): 569-600

[48] Ornelas, Emanuel and John Turner, 2005, "Trade Liberalization, Outsourcing, and the Hold-Up Problem", forthcoming in Journal of International Economics

[49] Ottaviano, Gianmarco I. P. and Alessandro Turrini, 2003, "Distance and FDI when Contracts are Incomplete", CEPR Discussion Paper Series No. 4041, Centre for Economic Policy Research, London

[50] Rauch, James E., 1999, "Networks versus Markets in International Trade", Journal of International Economics, 48: 7-35

[51] Romalis, John, 2004, "Factor Proportions and the Structure of Commodity Trade", The American Economic Review, 94: 67-97

[52] Santos Silva João M.C. and Silvana Tenreyro, 2005, "The Log of Gravity", forthcoming in The Review of Economics and Statistics

[53] Swenson, Deborah L., 2005, "Overseas Assembly and Country Sourcing Choices", Journal of International Economics, 66: 107-130

[54] U.S. Bureau of Economic Analysis, 1998, "U.S. Direct Investment Abroad: 1994 Benchmark Survey, Final Results", U.S. Government Printing Office, Washington, DC

[55] U.S. Bureau of Economic Analysis, 2004, "U.S. Direct Investment Abroad: Final Results From the 1999 Benchmark Survey", U.S. Government Printing Office, Washington, DC 
[56] U.S. Census Bureau, 1996, "1997 Economic Census General Summary. Manufacturing", Subject Series

[57] U.S. Census Bureau, 2001, "1992 Census of Manufacturers. General Summary", Subject Series

[58] Wheeler, David and Ashoka Mody, 1992, "International Investment Location Decisions: The Case of U.S. Firms", Journal of International Economics, 33: 57-75

[59] Wei, Shang-Jin, 2000, "How Taxing is Corruption on International Investors?", The Review of Economics and Statistics, 82(1): 1-11

[60] Williamson, Oliver, 1975, Markets and Hierarchies: Analysis and Antitrust Implications, Free Press, New York.

[61] Wooldridge Jeffrey M., 2002, Econometric Analysis of Cross Section and Panel Data, MIT Press, Cambridge (MA)

[62] Yeaple, Stephen Ross, 2003, "The Role of Skill Endowments in the Structure of U.S. Outward Foreign Direct Investment", The Review of Economics and Statistics, 85(3): 726-734

[63] Yeaple, Stephen Ross, 2006, "Offshoring, Foreign Direct Investment, and the Structure of U.S. Trade", Papers and Proceedings, Journal of the European Economic Association, 4: 602-611

\section{Tables}

\begin{tabular}{lrrrrrr} 
& voice & polstab & goveff & regqual & rulelaw & contrcorr \\
\hline \hline voice & 1 & & & & & \\
polstab & 0.75 & 1 & & & & \\
goveff & 0.76 & 0.83 & 1 & & & \\
regqual & 0.71 & 0.77 & 0.89 & 1 & & \\
rulelaw & 0.74 & 0.88 & 0.94 & 0.84 & 1 & \\
contrcorr & 0.76 & 0.83 & 0.95 & 0.84 & 0.96 & 1 \\
\hline \hline
\end{tabular}

All correlations are significant at $1 \%$ level

Table 1: Correlations between Different Measures of Institutional Quality 


\begin{tabular}{lrrrrr} 
Variable & Nobs & Mean & Std. Dev. & Min & Max \\
\hline \hline Total intrafirm trade & 655 & 563.52 & 4239.36 & 0 & 81829 \\
Trade to U.S. parents & 576 & 313.35 & 2378.82 & 0 & 44697 \\
Trade to foreign affiliates & 589 & 320.23 & 2151.56 & 0 & 37132 \\
Further manifacturing & 590 & 284.55 & 1870.35 & 0 & 35059 \\
Resale & 630 & 17.76 & 322.88 & 0 & 7990 \\
\hline \hline
\end{tabular}

Table 2: Descriptive Statistics

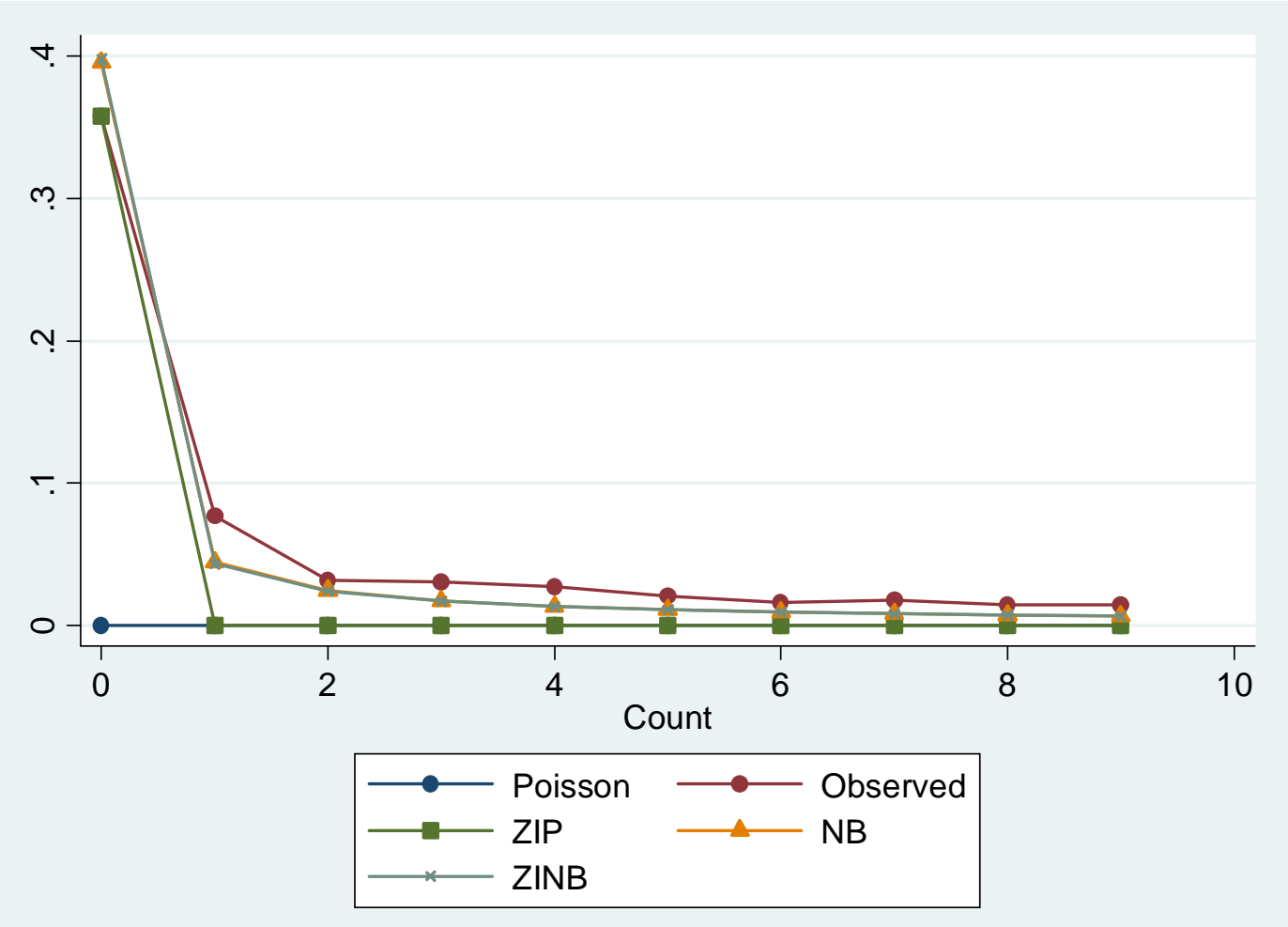

Figure 1: Distributions 
Dep Var: Total intrafirm flows

\begin{tabular}{|c|c|c|c|c|c|}
\hline & Poisson & ZIP & $\mathrm{NB}$ & ZINB & OLS \\
\hline inst $_{\mathrm{i}}{ }^{*}$ inst $_{\mathrm{c}}$ & $\begin{array}{c}6.90 * * * \\
(.011)\end{array}$ & $\begin{array}{c}6.79 * * * \\
(.011)\end{array}$ & $\begin{array}{c}7.76^{* * *} \\
(.919)\end{array}$ & $\begin{array}{c}7.92 * * * \\
(.927)\end{array}$ & $\begin{array}{c}6.43^{* * * *} \\
(.848)\end{array}$ \\
\hline constant & $\begin{array}{c}4.62 * * * \\
(.004)\end{array}$ & $\begin{array}{c}5.08^{* * *} \\
(.004)\end{array}$ & $\begin{array}{c}4.42^{* * *} \\
(.195)\end{array}$ & $\begin{array}{c}4.40^{* * * *} \\
(.194)\end{array}$ & $\begin{array}{c}2.55^{* * *} \\
(.191)\end{array}$ \\
\hline Inflated & & & & & \\
\hline inst $_{\mathrm{i}}{ }^{\text {inst }_{\mathrm{c}}}$ & & $\begin{array}{l}-.347 \\
(.595)\end{array}$ & & $\begin{array}{l}128.32 \\
(92.85)\end{array}$ & \\
\hline constant & & $\begin{array}{c}-.526 * * * \\
(.131)\end{array}$ & & $\begin{array}{l}-69.04 \\
(49.78) \\
\end{array}$ & \\
\hline Log Likelihood & -846292 & -692923 & -2801 & -2798 & \\
\hline BIC & 1688567 & 1381841 & 1590 & 1598 & \\
\hline AIC & 2703 & 2213 & 8.96 & 8.96 & \\
\hline Specification Tests & $\begin{array}{c}1690356 \\
0.000\end{array}$ & $\begin{array}{c}5.75 \\
0.000\end{array}$ & $\begin{array}{c}1.7 \mathrm{e}+06 \\
0.000\end{array}$ & $\begin{array}{c}0.70 \\
0.242\end{array}$ & \\
\hline Adjusted $\mathrm{R}^{2}$ & & & & & 0.12 \\
\hline BP Test & & & & & $\begin{array}{c}7.95 \\
(0.004)\end{array}$ \\
\hline SF Test & & & & & $\begin{array}{c}6.21 \\
(0.000)\end{array}$ \\
\hline
\end{tabular}

Standard errors in parentheses; * significant at 10\%; ** significant at 5\%; *** significant at $1 \%$

Table 3: Choice of the Estimator 
Dep. Var: Total intra-firm flows

\begin{tabular}{|c|c|c|c|c|c|c|}
\hline & $(1)$ & $(2)$ & (3) & (4) & $(5)$ & (6) \\
\hline \multirow[t]{2}{*}{ inst $_{\mathrm{i}}{ }^{*}$ inst $_{\mathrm{c}}$} & $7.093^{* * *}$ & $4.552 *$ & $7.413^{* * *}$ & $8.348^{* * *}$ & $9.048^{* * *}$ & $6.368 * *$ \\
\hline & $(2.28)$ & $(2.35)$ & $(2.54)$ & (2.69) & $(2.58)$ & $(3.08)$ \\
\hline \multirow[t]{2}{*}{ inst $_{\mathrm{c}}$} & 0.376 & -0.0393 & 0.0890 & 0.377 & -0.604 & -0.363 \\
\hline & $(0.74)$ & $(0.80)$ & $(0.91)$ & $(1.08)$ & $(1.08)$ & $(1.27)$ \\
\hline \multirow[t]{2}{*}{ inst $_{i}$} & -1.176 & -0.142 & $4.427^{* *}$ & $-4.753 * *$ & -3.192 & 3.693 \\
\hline & $(1.44)$ & (1.66) & (1.82) & $(2.30)$ & (2.29) & (3.95) \\
\hline \multirow[t]{2}{*}{ sales } & $1.722^{* * *}$ & $1.832 * * *$ & -0.251 & $2.034 * * *$ & 0.510 & $1.616^{* *}$ \\
\hline & $(0.25)$ & $(0.48)$ & $(0.48)$ & $(0.32)$ & $(0.42)$ & $(0.67)$ \\
\hline \multirow[t]{2}{*}{ market size } & $1.143^{* * *}$ & $0.928 * * *$ & $1.118 * * *$ & $1.184 * * *$ & $1.201 * * *$ & $1.020 * * *$ \\
\hline & $(0.086)$ & $(0.13)$ & $(0.099)$ & $(0.087)$ & $(0.096)$ & (0.13) \\
\hline \multirow[t]{2}{*}{ tariff } & & $-0.0114 * *$ & & & & $-0.0167 * * *$ \\
\hline & & $(0.0049)$ & & & & $(0.0057)$ \\
\hline \multirow[t]{2}{*}{ corp. scale } & & $0.0295^{*}$ & & & & $0.0537 *$ \\
\hline & & $(0.016)$ & & & & $(0.031)$ \\
\hline \multirow[t]{2}{*}{ plant scale } & & $-0.0382 * * *$ & & & & $-0.0620 * *$ \\
\hline & & $(0.0088)$ & & & & (0.029) \\
\hline \multirow[t]{2}{*}{ freight } & & $-21.19 * * *$ & & & & $-23.16^{* * *}$ \\
\hline & & (3.69) & & & & (3.78) \\
\hline \multirow[t]{2}{*}{ corp. tax rate } & & 0.0136 & & & & 0.0154 \\
\hline & & $(0.020)$ & & & & $(0.020)$ \\
\hline \multirow[t]{2}{*}{ NTB } & & 0.953 & & & & 0.901 \\
\hline & & $(0.61)$ & & & & $(0.73)$ \\
\hline \multirow[t]{2}{*}{ capital $_{\mathrm{i}}{ }^{*}$ capital $_{\mathrm{c}}$} & & & -2.457 & & $-5.782 * * *$ & $-8.592 * * *$ \\
\hline & & & $(1.54)$ & & (1.69) & $(2.11)$ \\
\hline \multirow[t]{2}{*}{ capital $_{\mathrm{c}}$} & & & $1.969 *$ & & $4.363 * * *$ & $6.277^{* * *}$ \\
\hline & & & $(1.10)$ & & (1.18) & $(1.46)$ \\
\hline \multirow[t]{2}{*}{ capital $_{\mathrm{i}}$} & & & $38.33 * *$ & & $74.56^{* * *}$ & $86.63^{* * *}$ \\
\hline & & & (16.4) & & (17.9) & $(22.7)$ \\
\hline \multirow[t]{2}{*}{ skill $_{\mathrm{i}}^{*}$ skill $_{\mathrm{c}}$} & & & & $-53.83 * *$ & $-82.08 * * *$ & $-106.7^{* * *}$ \\
\hline & & & & (25.6) & $(29.1)$ & $(30.6)$ \\
\hline \multirow[t]{2}{*}{ skill $_{\mathrm{c}}$} & & & & 3.567 & $6.481^{* *}$ & $8.742^{* *}$ \\
\hline & & & & $(2.81)$ & $(3.05)$ & $(3.42)$ \\
\hline \multirow[t]{2}{*}{ skill $_{\mathrm{i}}$} & & & & $57.74 * *$ & $109.0^{* * *}$ & 30.41 \\
\hline & & & & $(23.2)$ & (25.9) & $(47.3)$ \\
\hline \multirow[t]{2}{*}{ constant } & $-47.03 * * *$ & $-40.67 * * *$ & $-52.70 * * *$ & $-55.51 * * *$ & $-97.58 * * *$ & $-106.4^{* * *}$ \\
\hline & (3.83) & (6.69) & (12.1) & $(5.11)$ & $(14.7)$ & (17.9) \\
\hline \multirow[t]{2}{*}{ LR test $\mathrm{H}_{0}: \alpha=0$} & $1.4 \mathrm{e}+06$ & $4.9 e+05$ & $1.3 e+06$ & $1.3 e+06$ & $1.3 e+06$ & $4.7 e+05$ \\
\hline & $(0.000)$ & $(0.000)$ & $(0.000)$ & $(0.000)$ & $(0.000)$ & $(0.000)$ \\
\hline Observations & 603 & 425 & 585 & 585 & 585 & 425 \\
\hline Log likelihood & -2641 & -2031 & -2613 & -2615 & -2597 & -2012 \\
\hline
\end{tabular}

Standard errors in parentheses; * significant at 10\%; ** significant at 5\%; *** significant at $1 \%$

Table 4: Total Intra-firm Trade 
Dep. Var.: Intra-firm trade to U.S. parents

\begin{tabular}{|c|c|c|c|c|c|c|}
\hline & $(1)$ & $(2)$ & $(3)$ & $(4)$ & $(5)$ & $(6)$ \\
\hline \multirow[t]{2}{*}{ inst $_{\mathrm{i}}{ }^{*}$ inst $_{\mathrm{c}}$} & 3.506 & 1.347 & 5.252 & 1.412 & 4.347 & -0.00853 \\
\hline & $(3.31)$ & (3.39) & $(4.12)$ & $(4.05)$ & $(4.28)$ & $(4.48)$ \\
\hline \multirow[t]{2}{*}{ inst $_{c}$} & $2.603^{* *}$ & 0.919 & 2.038 & $4.518 * * *$ & $3.571 *$ & $3.752 *$ \\
\hline & (1.10) & (1.19) & $(1.55)$ & (1.72) & $(2.03)$ & $(2.14)$ \\
\hline \multirow[t]{2}{*}{ inst $_{\mathrm{i}}$} & 1.903 & 0.322 & $5.925^{* *}$ & 0.857 & 0.603 & $14.92^{* *}$ \\
\hline & (2.08) & $(2.41)$ & $(2.59)$ & (3.39) & (3.35) & $(6.54)$ \\
\hline \multirow[t]{2}{*}{ sales } & $1.665^{* * *}$ & $3.119 * * *$ & -0.114 & $1.996^{* * *}$ & 0.624 & $1.909 * *$ \\
\hline & $(0.35)$ & $(0.82)$ & $(0.73)$ & $(0.46)$ & $(0.63)$ & $(0.97)$ \\
\hline \multirow[t]{2}{*}{ market size } & $1.060 * * *$ & $0.816^{* * *}$ & $1.044^{* * *}$ & $1.147^{* * *}$ & $1.208^{* * *}$ & $1.169 * * *$ \\
\hline & $(0.12)$ & $(0.21)$ & $(0.16)$ & $(0.13)$ & $(0.17)$ & $(0.20)$ \\
\hline \multirow[t]{2}{*}{ tariff } & & -0.0214 & & & & $-0.0859 * * *$ \\
\hline & & $(0.020)$ & & & & $(0.027)$ \\
\hline \multirow[t]{2}{*}{ corp. scale } & & -0.0233 & & & & -0.00223 \\
\hline & & $(0.028)$ & & & & $(0.053)$ \\
\hline \multirow[t]{2}{*}{ plant scale } & & -0.0129 & & & & -0.0573 \\
\hline & & $(0.016)$ & & & & $(0.042)$ \\
\hline \multirow[t]{2}{*}{ freight } & & $-38.85 * * *$ & & & & $-45.14 * * *$ \\
\hline & & (8.39) & & & & (9.05) \\
\hline \multirow[t]{2}{*}{ corp. tax rate } & & 0.000650 & & & & 0.0427 \\
\hline & & $(0.040)$ & & & & $(0.034)$ \\
\hline \multirow[t]{2}{*}{ NTB } & & $-2.017^{* *}$ & & & & -0.938 \\
\hline & & $(0.95)$ & & & & (1.05) \\
\hline \multirow[t]{2}{*}{ capital $_{\mathrm{i}}^{*}$ capital $_{\mathrm{c}}$} & & & -1.615 & & $-5.353 * *$ & $-13.31^{* * *}$ \\
\hline & & & (2.38) & & (2.56) & (3.38) \\
\hline \multirow[t]{2}{*}{ capital $_{\mathrm{c}}$} & & & 1.254 & & $3.726^{* *}$ & $8.558 * * *$ \\
\hline & & & $(1.74)$ & & (1.86) & $(2.40)$ \\
\hline \multirow[t]{2}{*}{ capital $_{\mathrm{i}}$} & & & 28.45 & & $68.79 * *$ & $140.2^{* * *}$ \\
\hline & & & (25.1) & & (27.3) & (34.8) \\
\hline \multirow[t]{2}{*}{ skill $_{\mathrm{i}}^{*}$ skill $_{\mathrm{c}}$} & & & & -31.61 & -63.77 & $-185.9 * * *$ \\
\hline & & & & (34.0) & $(40.8)$ & (45.9) \\
\hline \multirow[t]{2}{*}{ skill $_{\mathrm{c}}$} & & & & -0.192 & 3.080 & $15.08^{* * *}$ \\
\hline & & & & (3.85) & $(4.44)$ & (5.17) \\
\hline \multirow[t]{2}{*}{ skill $_{\mathrm{i}}$} & & & & 32.51 & $83.94 * *$ & 27.47 \\
\hline & & & & (30.7) & (36.4) & (66.5) \\
\hline \multirow[t]{2}{*}{ constant } & $-46.48^{* * *}$ & $-52.24 * * *$ & $-46.16^{* *}$ & $-53.99 * * *$ & $-91.40 * * *$ & $-141.9 * * *$ \\
\hline & (5.29) & (11.3) & (18.3) & $(7.02)$ & (21.7) & (28.0) \\
\hline \multirow[t]{2}{*}{ LR test $\mathrm{H}_{0}: \alpha=0$} & $7.3 e+05$ & $2.6 \mathrm{e}+05$ & $7.1 \mathrm{e}+05$ & $6.9 \mathrm{e}+05$ & $6.7 \mathrm{e}+05$ & $2.4 \mathrm{e}+05$ \\
\hline & $(0.000)$ & $(0.000)$ & $(0.000)$ & $(0.000)$ & $(0.000)$ & $(0.000)$ \\
\hline Observations & 526 & 365 & 509 & 509 & 509 & 365 \\
\hline Log likelihood & -1683 & -1296 & -1672 & -1668 & -1662 & -1272 \\
\hline
\end{tabular}

Standard errors in parentheses; * significant at $10 \%$; ${ }^{* *}$ significant at $5 \%$; ${ }^{* * *}$ significant at $1 \%$

Table 5: Intra-firm Trade to U.S. Parents 
Dep. Var.: Intra-firm trade to foreign affiliates

\begin{tabular}{|c|c|c|c|c|c|c|}
\hline & $(1)$ & $(2)$ & (3) & $(4)$ & $(5)$ & $(6)$ \\
\hline \multirow{2}{*}{ inst $_{\mathrm{i}} *$ inst $_{\mathrm{c}}$} & $7.029 * * *$ & $4.255^{* * *}$ & $6.224^{* * *}$ & $9.105^{* * *}$ & $8.680^{* * *}$ & $6.319 * *$ \\
\hline & (2.11) & $(2.14)$ & $(2.24)$ & $(2.50)$ & (2.31) & (2.94) \\
\hline \multirow[t]{2}{*}{ inst $_{c}$} & -0.465 & -0.0639 & -0.480 & -0.960 & $-1.746^{*}$ & -1.382 \\
\hline & $(0.70)$ & $(0.74)$ & $(0.81)$ & $(0.95)$ & $(0.91)$ & (1.19) \\
\hline \multirow[t]{2}{*}{ inst $_{\mathrm{i}}$} & -2.112 & -0.474 & $4.413^{* * *}$ & $-5.359 * *$ & -2.885 & 2.966 \\
\hline & (1.34) & $(1.54)$ & (1.67) & $(2.21)$ & (2.19) & (3.70) \\
\hline \multirow[t]{2}{*}{ sales } & $1.635^{* * *}$ & $1.065^{* * *}$ & -0.374 & $1.858 * * *$ & 0.260 & 0.958 \\
\hline & $(0.24)$ & $(0.43)$ & $(0.41)$ & $(0.30)$ & $(0.39)$ & $(0.64)$ \\
\hline \multirow[t]{2}{*}{ market size } & $1.210 * * *$ & $1.028 * * *$ & $1.231^{* * * *}$ & $1.221^{* * * *}$ & $1.264 * * *$ & $1.076 * * *$ \\
\hline & $(0.079)$ & $(0.11)$ & $(0.089)$ & $(0.083)$ & $(0.088)$ & $(0.12)$ \\
\hline \multirow[t]{2}{*}{ tariff } & & $-0.0108 * *$ & & & & $-0.0126 * *$ \\
\hline & & (0.0048) & & & & $(0.0058)$ \\
\hline \multirow[t]{2}{*}{ corp. scale } & & $0.0510^{* * *}$ & & & & $0.0532 *$ \\
\hline & & (0.014) & & & & $(0.029)$ \\
\hline \multirow[t]{2}{*}{ plant scale } & & $-0.0360 * * *$ & & & & $-0.0510 *$ \\
\hline & & (0.0078) & & & & $(0.027)$ \\
\hline \multirow[t]{2}{*}{ freight } & & $-18.88 * * *$ & & & & $-18.07^{* * *}$ \\
\hline & & (3.47) & & & & (3.60) \\
\hline \multirow[t]{2}{*}{ corp. tax rate } & & 0.00447 & & & & -0.00993 \\
\hline & & $(0.018)$ & & & & $(0.019)$ \\
\hline \multirow[t]{2}{*}{ NTB } & & $1.775^{* * *}$ & & & & $1.321^{*}$ \\
\hline & & $(0.60)$ & & & & $(0.69)$ \\
\hline \multirow[t]{2}{*}{ capital $_{\mathrm{i}}^{*}$ capital $_{\mathrm{c}}$} & & & $-3.476^{* *}$ & & $-5.693 * * *$ & $-6.109 * * *$ \\
\hline & & & $(1.42)$ & & (1.57) & (1.81) \\
\hline \multirow[t]{2}{*}{ capital $_{\mathrm{c}}$} & & & $2.705^{* * *}$ & & $4.379 * * *$ & $4.778 * * *$ \\
\hline & & & (1.00) & & (1.09) & $(1.28)$ \\
\hline \multirow[t]{2}{*}{ capital $_{\mathrm{i}}$} & & & $49.66^{* * *}$ & & $74.45^{* * *}$ & $62.91^{* * *}$ \\
\hline & & & (15.1) & & (16.6) & (20.0) \\
\hline \multirow[t]{2}{*}{ skill $_{i}^{*}{ }^{*}$ kkill $_{\mathrm{c}}$} & & & & $-43.59 *$ & $-69.21^{* *}$ & $-74.70^{* * * *}$ \\
\hline & & & & (25.3) & (27.8) & (28.9) \\
\hline \multirow[t]{2}{*}{ skill $_{\mathrm{c}}$} & & & & 3.632 & $6.431 * *$ & $6.896 * *$ \\
\hline & & & & $(2.69)$ & $(2.83)$ & $(3.12)$ \\
\hline \multirow[t]{2}{*}{ skill $_{\mathrm{i}}$} & & & & $47.93^{* *}$ & $99.19 * * *$ & 20.59 \\
\hline & & & & (23.4) & (25.0) & $(44.8)$ \\
\hline \multirow[t]{2}{*}{ constant } & $-47.46 * * *$ & $-34.90 * * *$ & $-62.29 * * *$ & $-53.84 * * *$ & $-96.69 * * *$ & $-85.36 * * *$ \\
\hline & $(3.64)$ & $(5.73)$ & (11.1) & $(5.07)$ & (13.8) & $(15.7)$ \\
\hline \multirow[t]{2}{*}{ LR test $\mathrm{H}_{0}: \alpha=0$} & $6.0 \mathrm{e}+05$ & $2.3 e+05$ & $5.8 \mathrm{e}+05$ & $5.7 e+05$ & $5.5 e+05$ & $2.2 \mathrm{e}+05$ \\
\hline & $(0.000)$ & $(0.000)$ & $(0.000)$ & $(0.000)$ & $(0.000)$ & $(0.000)$ \\
\hline Observations & 541 & 381 & 524 & 524 & 524 & 381 \\
\hline Log likelihood & -2315 & -1788 & -2281 & -2295 & -2271 & -1778 \\
\hline
\end{tabular}

Standard errors in parentheses; * significant at $10 \%$; ** significant at 5\%; *** significant at $1 \%$

Table 6: Intra-firm Trade to Foreign Affiliates 
Dep. Var.: Goods for further manufacturing

\begin{tabular}{|c|c|c|c|c|c|c|}
\hline & (1) & (2) & (3) & (4) & (5) & (6) \\
\hline inst $_{i}{ }^{*}$ inst $_{c}$ & $\begin{array}{c}7.221^{* * *} \\
(2.15)\end{array}$ & $\begin{array}{c}5.830 * * \\
(2.28)\end{array}$ & $\begin{array}{c}6.533^{* * *} \\
(2.27)\end{array}$ & $\begin{array}{c}9.224^{* * *} \\
(2.49)\end{array}$ & $\begin{array}{c}8.892^{* * *} \\
(2.29)\end{array}$ & $\begin{array}{c}8.708^{* * *} \\
(3.00)\end{array}$ \\
\hline inst $_{\mathrm{c}}$ & $\begin{array}{l}-0.620 \\
(0.72)\end{array}$ & $\begin{array}{l}-0.884 \\
(0.80)\end{array}$ & $\begin{array}{r}-0.630 \\
(0.83)\end{array}$ & $\begin{array}{c}-1.105 \\
(0.95)\end{array}$ & $\begin{array}{c}-1.949 * * \\
(0.90)\end{array}$ & $\begin{array}{c}-2.203^{*} \\
(1.23)\end{array}$ \\
\hline inst $_{i}$ & $\begin{array}{l}-2.147 \\
(1.37)\end{array}$ & $\begin{array}{l}-1.167 \\
(1.63)\end{array}$ & $\begin{array}{c}3.939 * * \\
(1.69)\end{array}$ & $\begin{array}{c}-5.982 * * * \\
(2.22)\end{array}$ & $\begin{array}{c}-3.910 * \\
(2.19)\end{array}$ & $\begin{array}{l}-0.517 \\
(3.78)\end{array}$ \\
\hline sales & $\begin{array}{c}1.627 * * * \\
(0.24)\end{array}$ & $\begin{array}{c}0.943^{* *} \\
(0.43)\end{array}$ & $\begin{array}{l}-0.257 \\
(0.41)\end{array}$ & $\begin{array}{c}1.912^{* * *} \\
(0.30)\end{array}$ & $\begin{array}{c}0.432 \\
(0.39)\end{array}$ & $\begin{array}{l}0.867 \\
(0.64)\end{array}$ \\
\hline market size & $\begin{array}{c}1.179 * * * \\
(0.079)\end{array}$ & $\begin{array}{c}0.999 * * * \\
(0.12)\end{array}$ & $\begin{array}{c}1.207 * * * \\
(0.091)\end{array}$ & $\begin{array}{c}1.196^{* * *} \\
(0.083)\end{array}$ & $\begin{array}{c}1.246 * * * \\
(0.090)\end{array}$ & $\begin{array}{c}1.024^{* * *} \\
(0.12)\end{array}$ \\
\hline tariff & & $\begin{array}{c}-0.0123^{* *} \\
(0.0050)\end{array}$ & & & & $\begin{array}{c}-0.0132 * * \\
(0.0061)\end{array}$ \\
\hline corp. scale & & $\begin{array}{c}0.0511^{* * *} \\
(0.014)\end{array}$ & & & & $\begin{array}{c}0.0531^{*} \\
(0.029)\end{array}$ \\
\hline plant scale & & $\begin{array}{c}-0.0353^{* * *} \\
(0.0078)\end{array}$ & & & & $\begin{array}{c}-0.0420 \\
(0.028)\end{array}$ \\
\hline freight & & $\begin{array}{c}-18.17^{* * *} \\
(3.49)\end{array}$ & & & & $\begin{array}{c}-17.04^{* * *} \\
(3.69)\end{array}$ \\
\hline corp. tax rate & & $\begin{array}{c}0.00870 \\
(0.018)\end{array}$ & & & & $\begin{array}{c}0.00108 \\
(0.020)\end{array}$ \\
\hline NTB & & $\begin{array}{c}1.357 * * \\
(0.61)\end{array}$ & & & & $\begin{array}{l}0.925 \\
(0.69)\end{array}$ \\
\hline capital $_{\mathrm{i}}{ }^{*}$ capital $_{\mathrm{c}}$ & & & $\begin{array}{c}-3.459 * * \\
(1.43)\end{array}$ & & $\begin{array}{c}-5.784 * * * \\
(1.57)\end{array}$ & $\begin{array}{c}-4.218^{* *} \\
(1.77)\end{array}$ \\
\hline capital $_{\mathrm{c}}$ & & & $\begin{array}{c}2.658^{* * *} \\
(1.00)\end{array}$ & & $\begin{array}{c}4.425^{* * *} \\
(1.09)\end{array}$ & $\begin{array}{c}3.365^{* * *} \\
(1.25)\end{array}$ \\
\hline capital $_{\mathrm{i}}$ & & & $\begin{array}{c}48.74^{* * *} \\
(15.2)\end{array}$ & & $\begin{array}{c}74.91^{* * *} \\
(16.7)\end{array}$ & $\begin{array}{c}43.54^{* *} \\
(20.3)\end{array}$ \\
\hline skill $_{\mathrm{i}}^{*}$ skill $_{\mathrm{c}}$ & & & & $\begin{array}{c}-45.41^{*} \\
(25.7)\end{array}$ & $\begin{array}{c}-70.01^{* *} \\
(28.3)\end{array}$ & $\begin{array}{c}-70.85^{* *} \\
(29.0)\end{array}$ \\
\hline skill $_{\mathrm{C}}$ & & & & $\begin{array}{l}3.704 \\
(2.73)\end{array}$ & $\begin{array}{c}6.426^{* *} \\
(2.88)\end{array}$ & $\begin{array}{c}6.299 * * \\
(3.11)\end{array}$ \\
\hline skill $_{\mathrm{i}}$ & & & & $\begin{array}{c}53.78 * * \\
(23.7)\end{array}$ & $\begin{array}{c}104.8^{* * * *} \\
(25.2)\end{array}$ & $\begin{array}{l}34.57 \\
(46.3)\end{array}$ \\
\hline constant & $\begin{array}{c}-46.57^{* * *} \\
(3.65) \\
\end{array}$ & $\begin{array}{c}-32.44^{* * *} \\
(5.68) \\
\end{array}$ & $\begin{array}{c}-62.03^{* * *} \\
(11.2) \\
\end{array}$ & $\begin{array}{c}-54.18^{* * *} \\
(5.08) \\
\end{array}$ & $\begin{array}{c}-98.66^{* * *} \\
(13.8) \\
\end{array}$ & $\begin{array}{c}-69.32^{* * *} \\
(15.7) \\
\end{array}$ \\
\hline LR test $\mathrm{H}_{0}: \mathrm{\alpha}=0$ & $\begin{array}{c}5.3 e+05 \\
(0.000)\end{array}$ & $\begin{array}{c}2.0 \mathrm{e}+05 \\
(0.000)\end{array}$ & $\begin{array}{c}5.2 \mathrm{e}+05 \\
(0.000)\end{array}$ & $\begin{array}{c}5.0 \mathrm{e}+05 \\
(0.000)\end{array}$ & $\begin{array}{c}4.9 e+05 \\
(0.000)\end{array}$ & $\begin{array}{c}2.0 \mathrm{e}+05 \\
(0.000)\end{array}$ \\
\hline Observations & $\begin{array}{c}542 \\
-2275\end{array}$ & $\begin{array}{c}385 \\
-1770\end{array}$ & $\begin{array}{c}526 \\
-2245\end{array}$ & $\begin{array}{c}526 \\
-2255\end{array}$ & $\begin{array}{c}526 \\
-2233\end{array}$ & $\begin{array}{c}385 \\
-1763\end{array}$ \\
\hline
\end{tabular}

Standard errors in parentheses; * significant at $10 \%$; ${ }^{* *}$ significant at $5 \%$; $* * *$ significant at $1 \%$

Table 7: Trade in Goods for Further Manufacturing 
Dep. Var.: Goods for resale

\begin{tabular}{|c|c|c|c|c|c|c|}
\hline & $(1)$ & $(2)$ & $(3)$ & $(4)$ & (5) & $(6)$ \\
\hline \multirow{2}{*}{ inst $_{\mathrm{i}}{ }^{*}$ inst $_{\mathrm{c}}$} & $19.47 * * *$ & 5.279 & $28.04 * * *$ & 20.25 & 14.57 & -12.09 \\
\hline & (6.90) & (6.74) & (9.05) & (12.6) & (11.5) & (12.7) \\
\hline \multirow[t]{2}{*}{ inst $_{c}$} & -1.675 & 1.958 & -6.441 & $-7.504^{*}$ & -6.054 & 5.103 \\
\hline & $(2.82)$ & $(2.43)$ & $(4.21)$ & $(4.17)$ & $(4.24)$ & $(4.92)$ \\
\hline \multirow[t]{2}{*}{ inst $_{\mathrm{i}}$} & $-17.71^{* * * *}$ & -6.250 & -9.005 & -11.56 & 4.107 & 12.47 \\
\hline & $(5.50)$ & (5.37) & (8.13) & (10.1) & (10.2) & (14.0) \\
\hline \multirow[t]{2}{*}{ sales } & $3.715^{* * *}$ & -1.148 & -0.758 & 2.137 & -1.876 & -1.447 \\
\hline & (1.04) & $(1.43)$ & $(1.22)$ & $(1.50)$ & (1.38) & $(2.20)$ \\
\hline \multirow[t]{2}{*}{ market size } & $2.658 * * *$ & $2.576^{* * *}$ & $2.398 * * *$ & $2.578 * * *$ & $2.490 * * *$ & $2.913^{* * *}$ \\
\hline & $(0.50)$ & $(0.51)$ & $(0.44)$ & $(0.46)$ & $(0.44)$ & $(0.59)$ \\
\hline \multirow[t]{2}{*}{ tariff } & & -0.0183 & & & & -0.0431 \\
\hline & & $(0.042)$ & & & & $(0.047)$ \\
\hline \multirow[t]{2}{*}{ corp. scale } & & $0.183^{* * *}$ & & & & 0.199* \\
\hline & & $(0.037)$ & & & & $(0.10)$ \\
\hline \multirow[t]{2}{*}{ plant scale } & & -0.0344 & & & & -0.0630 \\
\hline & & $(0.030)$ & & & & $(0.096)$ \\
\hline \multirow[t]{2}{*}{ freight } & & -10.50 & & & & -8.581 \\
\hline & & (15.3) & & & & (15.7) \\
\hline \multirow[t]{2}{*}{ corp. tax rate } & & 0.0669 & & & & 0.0521 \\
\hline & & $(0.055)$ & & & & $(0.062)$ \\
\hline \multirow[t]{2}{*}{ NTB } & & 0.666 & & & & 0.211 \\
\hline & & $(2.10)$ & & & & $(2.18)$ \\
\hline \multirow[t]{2}{*}{ capital $_{\mathrm{i}}{ }^{\mathrm{c}}$ capital $_{\mathrm{c}}$} & & & 3.505 & & 5.378 & 4.230 \\
\hline & & & $(5.15)$ & & (5.92) & $(5.82)$ \\
\hline \multirow[t]{2}{*}{ capital $_{\mathrm{c}}$} & & & -1.485 & & -3.536 & -3.719 \\
\hline & & & (3.91) & & (4.54) & $(4.47)$ \\
\hline \multirow[t]{2}{*}{ capital $_{\mathrm{i}}$} & & & -8.325 & & -22.65 & -48.76 \\
\hline & & & (56.4) & & (63.8) & (66.1) \\
\hline \multirow[t]{2}{*}{$\operatorname{skill}_{\mathrm{i}}{ }^{*} \operatorname{skill}_{\mathrm{c}}$} & & & & -66.78 & 121.7 & $210.4^{* *}$ \\
\hline & & & & (117) & (117) & (101) \\
\hline \multirow[t]{2}{*}{ skill $_{\mathrm{c}}$} & & & & 13.09 & -4.708 & -16.10 \\
\hline & & & & (11.1) & (10.9) & $(10.00)$ \\
\hline \multirow[t]{2}{*}{ skill $_{\mathrm{i}}$} & & & & -1.395 & -117.9 & -243.2 \\
\hline & & & & (105) & (98.2) & (164) \\
\hline \multirow[t]{2}{*}{ constant } & $-113.3 * * *$ & $-59.77 * * *$ & -56.65 & $-95.21^{* * *}$ & -23.50 & -5.554 \\
\hline & $(17.5)$ & (20.5) & $(46.8)$ & $(23.6)$ & $(55.4)$ & $(50.0)$ \\
\hline \multirow[t]{2}{*}{ LR test $\mathrm{H}_{0}: \alpha=0$} & $7.2 \mathrm{e}+04$ & 9380.19 & $6.6 e+04$ & $3.5 e+04$ & $1.6 e+04$ & 5427.01 \\
\hline & $(0.000)$ & $(0.000)$ & $(0.000)$ & $(0.000)$ & $(0.000)$ & $(0.000)$ \\
\hline Observations & 577 & 396 & 559 & 559 & 559 & 396 \\
\hline Log likelihood & -299.1 & -254.2 & -290.5 & -296.0 & -287.4 & -251.1 \\
\hline
\end{tabular}

Standard errors in parentheses; * significant at 10\%; ** significant at 5\%; *** significant at $1 \%$

Table 8: Trade in Goods for Resale 


\begin{tabular}{lcccccc}
\hline \hline & $(1)$ & $(2)$ & $(3)$ & $(4)$ & $(5)$ & $(6)$ \\
\cline { 2 - 7 } Trade to foreign af. & $466.27^{* * *}$ & $335.69^{*}$ & $384.69^{* * *}$ & $642.14^{* * *}$ & $489.71^{* * *}$ & $444.05^{* *}$ \\
& $(147.02)$ & $(173.27)$ & $(143.34)$ & $(186.97)$ & $(138.58)$ & $(211.55)$ \\
Further manif. & $446.43^{* * *}$ & $419.55^{* *}$ & $376.8^{* * *}$ & $598.36^{* * *}$ & $459.87^{* * *}$ & $571.67 * * *$ \\
& $(139.86)$ & $(171.04)$ & $(136.6)$ & $(171.77)$ & $(127.01)$ & $(208.69)$ \\
\multirow{2}{*}{ Resale } & 1.688 & 0.450 & 1.533 & 1.960 & 0.623 & -0.733 \\
& $(1.085)$ & $(0.623)$ & $(1.075)$ & $(1.636)$ & $(0.713)$ & 0.688 \\
\hline \hline
\end{tabular}

Standard errors in parentheses; * significant at $10 \%$; ${ }^{* *}$ significant at $5 \%$; ${ }^{* * *}$ significant at $1 \%$

Table 9: Marginal Effects 


\begin{tabular}{|c|c|c|c|}
\hline \multicolumn{4}{|c|}{ Dep. Var.: Intrafirm trade to foreign affiliates } \\
\hline & (1) & (2) & (3) \\
\hline \multirow[t]{2}{*}{ inst $_{\mathrm{i}}$ inst $_{\mathrm{c}}$} & $8.51^{* * *}$ & $3.57^{*}$ & $6.55^{* * *}$ \\
\hline & $(1.97)$ & (2.15) & $(1.63)$ \\
\hline inst $_{\mathrm{i}}$ & $\begin{array}{c}-5.63 * * * \\
(1.32)\end{array}$ & & \\
\hline inst $_{c}$ & & $\begin{array}{l}1.54^{* *} \\
(0.715)\end{array}$ & \\
\hline Constant & $\begin{array}{l}4.41^{* * *} \\
(0.641)\end{array}$ & $\begin{array}{l}2.51^{* * * *} \\
(0.429)\end{array}$ & $\begin{array}{c}2.93 * * * \\
(0.59)\end{array}$ \\
\hline Observations & 561 & 561 & 561 \\
\hline \multicolumn{4}{|c|}{ Dep. Var: Goods for further manifacturing } \\
\hline inst $_{\mathrm{i}}^{*}$ inst $_{\mathrm{c}}$ & $\begin{array}{c}7.79 * * * \\
(2.01)\end{array}$ & $\begin{array}{c}3.51 \\
(2.16)\end{array}$ & $\begin{array}{c}7.00^{* * * *} \\
(1.65)\end{array}$ \\
\hline inst $_{\mathrm{i}}$ & $\begin{array}{c}-5.03^{* * *} \\
(1.33)\end{array}$ & & \\
\hline inst $_{c}$ & & $\begin{array}{l}1.42 * * \\
(0.719)\end{array}$ & \\
\hline Constant & $\begin{array}{l}4.42 * * * \\
(0.575)\end{array}$ & $\begin{array}{c}2.39 * * * \\
(0.43)\end{array}$ & $\begin{array}{l}2.38 * * * \\
(0.528)\end{array}$ \\
\hline Observations & 562 & 562 & 562 \\
\hline \multicolumn{4}{|c|}{ Dep. Var: Goods for resale } \\
\hline inst $_{\mathrm{i}}^{*}$ inst $_{\mathrm{c}}$ & $\begin{array}{c}8.38 \\
(8.17)\end{array}$ & $\begin{array}{c}3.45 \\
(7.18)\end{array}$ & $\begin{array}{l}0.222 \\
(6.67)\end{array}$ \\
\hline inst $_{\mathrm{i}}$ & $\begin{array}{c}-11.43^{*} \\
(5.89)\end{array}$ & & \\
\hline inst $_{c}$ & & $\begin{array}{l}7.10^{*} \\
(2.82)\end{array}$ & \\
\hline Constant & $\begin{array}{l}4.07 * \\
(2.17)\end{array}$ & $\begin{array}{c}-6.02 * * * \\
(1.84)\end{array}$ & $\begin{array}{l}-0.059 \\
(1.71)\end{array}$ \\
\hline Observations & 600 & 600 & 600 \\
\hline Country dummies & Yes & No & Yes \\
\hline Sector dummies & No & Yes & Yes \\
\hline Time dummy & Yes & Yes & Yes \\
\hline
\end{tabular}

Table 10: Alternative Specifications 


\begin{tabular}{|c|c|c|c|c|c|c|}
\hline \multirow[b]{2}{*}{ inst $_{\mathrm{i}}{ }^{\text {inst }_{\mathrm{c}}}$} & \multicolumn{2}{|c|}{$\begin{array}{c}\text { Intrafirm trade to foreign } \\
\text { affiliates }\end{array}$} & \multicolumn{2}{|c|}{$\begin{array}{c}\text { Goods for further } \\
\text { manifacturing }\end{array}$} & \multicolumn{2}{|c|}{ Goods for resale } \\
\hline & $\begin{array}{c}3.775^{* * *} \\
(0.99)\end{array}$ & $\begin{array}{l}3.777^{* * * *} \\
(0.99)\end{array}$ & $\begin{array}{l}3.706 * * * \\
(0.99)\end{array}$ & $\begin{array}{c}3.739 * * * \\
(0.99)\end{array}$ & $\begin{array}{l}3.571 \\
(3.72)\end{array}$ & $\begin{array}{l}2.963 \\
(3.64)\end{array}$ \\
\hline inst $_{i}$ & $\begin{array}{c}-3.332^{* * *} \\
(0.71)\end{array}$ & $\begin{array}{c}-3.299 * * * \\
(0.71)\end{array}$ & $\begin{array}{c}-3.216^{* * *} \\
(0.71)\end{array}$ & $\begin{array}{c}-3.210^{* * *} \\
(0.71)\end{array}$ & $\begin{array}{c}-5.830 * * \\
(2.85)\end{array}$ & $\begin{array}{c}-5.348 * \\
(2.75)\end{array}$ \\
\hline inst $_{c}$ & $\begin{array}{c}-0.739 * * \\
(0.36)\end{array}$ & $\begin{array}{c}-0.670 * \\
(0.35)\end{array}$ & $\begin{array}{c}-0.855^{* *} \\
(0.37)\end{array}$ & $\begin{array}{c}-0.786^{* *} \\
(0.36)\end{array}$ & $\begin{array}{l}0.852 \\
(1.49)\end{array}$ & $\begin{array}{l}-0.252 \\
(1.09)\end{array}$ \\
\hline sales & $\begin{array}{l}0.349 * * * \\
(0.10)\end{array}$ & $\begin{array}{c}0.349^{* * *} \\
(0.10)\end{array}$ & $\begin{array}{c}0.373^{* * *} \\
(0.10)\end{array}$ & $\begin{array}{l}0.371^{* * * *} \\
(0.10)\end{array}$ & $\begin{array}{c}0.891^{* *} \\
(0.35)\end{array}$ & $\begin{array}{c}0.874 * * \\
(0.35)\end{array}$ \\
\hline market size & $\begin{array}{c}0.281^{* * *} \\
(0.053)\end{array}$ & $\begin{array}{c}0.323 * * * \\
(0.051)\end{array}$ & $\begin{array}{c}0.300 * * * \\
(0.053)\end{array}$ & $\begin{array}{c}0.338 * * * \\
(0.050)\end{array}$ & $\begin{array}{l}0.320 \\
(0.31)\end{array}$ & $\begin{array}{l}0.785^{* * *} \\
\quad(0.16)\end{array}$ \\
\hline constant & $\begin{array}{l}-11.87^{* * *} \\
(1.88)\end{array}$ & $\begin{array}{c}-13.02^{* * *} \\
(1.82)\end{array}$ & $\begin{array}{c}-12.64^{* * *} \\
(1.86)\end{array}$ & $\begin{array}{c}-13.68 * * * \\
(1.81)\end{array}$ & $\begin{array}{c}-22.33^{* *} \\
(9.09)\end{array}$ & $\begin{array}{c}-33.90 * * * \\
(5.97)\end{array}$ \\
\hline Log likelihood & -1790 & -2205 & -1761 & -2171 & -160.3 & -288.2 \\
\hline Estimation & $\mathrm{FE}$ & $\mathrm{RE}$ & $\mathrm{FE}$ & $\mathrm{RE}$ & $\mathrm{FE}$ & $\mathrm{RE}$ \\
\hline Hausman test & \multicolumn{2}{|c|}{$\begin{array}{c}2.76 \\
(0.737)\end{array}$} & \multicolumn{2}{|c|}{$\begin{array}{c}4.47 \\
(0.484)\end{array}$} & \multicolumn{2}{|c|}{$\begin{array}{c}3.61 \\
(0.607)\end{array}$} \\
\hline
\end{tabular}

Standard errors in parentheses; * significant at $10 \%$; ** significant at $5 \%$; *** significant at $1 \%$; Estimates with country effects

Table 11: Panel Estimates: Fixed Effects versus Random Effects 


\begin{tabular}{|c|c|c|c|c|c|}
\hline & $\begin{array}{c}\text { Total intra-firm } \\
\text { flows } \\
\end{array}$ & $\begin{array}{c}\text { Intra-firm trade to } \\
\text { U.S. parents }\end{array}$ & $\begin{array}{l}\text { Inta-firm trade to } \\
\text { foreign affiliates }\end{array}$ & $\begin{array}{c}\text { Goods for further } \\
\text { manufacturing }\end{array}$ & Goods for resale \\
\hline \multirow[t]{2}{*}{ inst $_{\mathrm{i}} *$ inst $_{\mathrm{c}}$} & $4.111^{* * *}$ & 2.208 & $3.777 * * *$ & $3.739 * * *$ & 2.963 \\
\hline & $(0.98)$ & $(1.41)$ & $(0.99)$ & (0.99) & (3.64) \\
\hline \multirow[t]{2}{*}{ inst $_{\mathrm{i}}$} & $-3.251^{* * *}$ & -1.156 & $-3.299 * * *$ & $-3.210 * * *$ & $-5.348 *$ \\
\hline & $(0.71)$ & (1.04) & $(0.71)$ & $(0.71)$ & $(2.75)$ \\
\hline \multirow{2}{*}{ inst $_{c}$} & $-0.693 * *$ & 0.612 & $-0.670^{*}$ & $-0.786^{* *}$ & -0.252 \\
\hline & $(0.35)$ & $(0.52)$ & $(0.35)$ & $(0.36)$ & $(1.09)$ \\
\hline \multirow[t]{2}{*}{ sales } & $0.334^{* * *}$ & $0.335^{* * *}$ & $0.349 * * *$ & $0.371^{* * *}$ & $0.874^{* *}$ \\
\hline & $(0.099)$ & $(0.13)$ & $(0.10)$ & $(0.10)$ & $(0.35)$ \\
\hline \multirow[t]{2}{*}{ market size } & $0.324 * * *$ & $0.411^{* * *}$ & $0.323 * * *$ & $0.338 * * *$ & $0.785 * * *$ \\
\hline & $(0.049)$ & $(0.059)$ & $(0.051)$ & $(0.050)$ & $(0.16)$ \\
\hline \multirow[t]{2}{*}{ constant } & $-13.10 * * *$ & $-16.91 * * *$ & $-13.02 * * *$ & $-13.68 * * *$ & $-33.90 * * *$ \\
\hline & $(1.74)$ & $(2.21)$ & $(1.82)$ & $(1.81)$ & $(5.97)$ \\
\hline \multirow[t]{2}{*}{ LR test vs pooled } & 334.79 & 184.74 & 297.13 & 277.91 & 37.59 \\
\hline & $(0.000)$ & $(0.000)$ & $(0.000)$ & $(0.000)$ & $(0.000)$ \\
\hline Observations & 603 & 526 & 541 & 542 & 577 \\
\hline Log likelihood & -2509 & -1566 & -2205 & -2172 & -288.2 \\
\hline
\end{tabular}

Table 12: Panel Estimates with Country Effects 


\begin{tabular}{lccccc}
\hline \hline & $\begin{array}{c}\text { Total intra-firm } \\
\text { flows }\end{array}$ & $\begin{array}{c}\text { Intra-firm trade to } \\
\text { U.S. parents }\end{array}$ & $\begin{array}{c}\text { Inta-firm trade to } \\
\text { foreign affiliates }\end{array}$ & $\begin{array}{c}\text { Goods for further } \\
\text { manufacturing }\end{array}$ & Goods for resale \\
\cline { 2 - 6 } inst $_{\mathrm{i}}$ inst $_{\mathrm{c}}$ & $3.056^{* * *}$ & 1.741 & $2.802^{* *}$ & $2.950^{* * *}$ & 1.865 \\
& $(1.07)$ & $(1.51)$ & $(1.11)$ & $(1.10)$ & $(3.84)$ \\
inst $_{\mathrm{i}}$ & $-3.969^{* * *}$ & $-2.111^{*}$ & $-4.071^{* * *}$ & $-4.166^{* * *}$ & $-4.983^{*}$ \\
& $(0.78)$ & $(1.10)$ & $(0.80)$ & $(0.80)$ & $(2.89)$ \\
inst $_{\mathrm{c}}$ & -0.261 & 0.797 & -0.230 & -0.408 & 0.530 \\
& $(0.34)$ & $(0.52)$ & $(0.34)$ & $(0.35)$ & $(1.04)$ \\
sales & -0.0240 & 0.0548 & -0.0767 & -0.0371 & $0.841^{* *}$ \\
& $(0.11)$ & $(0.15)$ & $(0.12)$ & $(0.12)$ & $(0.34)$ \\
market size & $0.500^{* * *}$ & $0.548^{* * *}$ & $0.526 * * *$ & $0.527 * * *$ & $0.727^{* * *}$ \\
& $(0.037)$ & $(0.045)$ & $(0.037)$ & $(0.037)$ & $(0.11)$ \\
constant & $-13.70^{* * *}$ & $-17.51^{* * *}$ & $-13.48^{* * *}$ & $-13.89 * * *$ & $-33.39^{* * *}$ \\
& $(1.66)$ & $(2.12)$ & $(1.74)$ & $(1.75)$ & $(5.20)$ \\
LR test vs pooled & 129.36 & 40.64 & 132.44 & 129.6 & $8.2 \mathrm{e}-05$ \\
& $(0.000)$ & $(0.000)$ & $(0.000)$ & $(0.000)$ & $(0.496)$ \\
Observations & 603 & 526 & 541 & 542 & 577 \\
Log likelihood & -2612 & -1638 & -2287 & -2246 & -307.0 \\
\hline \hline
\end{tabular}

Panel estimates with sector random effects. Standard errors in parentheses; * significant at $10 \%$; ** significant at $5 \%$; *** significant at $1 \%$

Table 13: Panel Estimates with Sector Effects 


\begin{tabular}{lccccc}
\hline \hline & $\begin{array}{c}\text { Total intra-firm } \\
\text { flows }\end{array}$ & $\begin{array}{c}\text { Intra-firm trade to } \\
\text { U.S. parents }\end{array}$ & $\begin{array}{c}\text { Inta-firm trade to } \\
\text { foreign affiliates }\end{array}$ & $\begin{array}{c}\text { Goods for further } \\
\text { manufacturing }\end{array}$ & Goods for resale \\
\cline { 2 - 6 } inst $_{\mathrm{i}}{ }^{\text {inst }} \mathrm{c}$ & $1.990^{*}$ & 0.597 & $2.282^{* *}$ & $2.155^{* *}$ & -0.867 \\
& $(1.03)$ & $(1.47)$ & $(1.03)$ & $(1.04)$ & $(6.23)$ \\
inst $_{\mathrm{i}}$ & -0.434 & 0.951 & -0.842 & -0.789 & 2.497 \\
& $(0.73)$ & $(1.06)$ & $(0.70)$ & $(0.71)$ & $(4.98)$ \\
inst $_{\mathrm{c}}$ & $1.531^{* *}$ & $3.414^{* * *}$ & 0.571 & 0.562 & 3.777 \\
& $(0.65)$ & $(0.98)$ & $(0.62)$ & $(0.62)$ & $(3.30)$ \\
sales & $2.320^{* * *}$ & $2.551^{* * *}$ & $2.059^{* * *}$ & $2.047^{* * *}$ & $3.200^{* * *}$ \\
& $(0.24)$ & $(0.34)$ & $(0.22)$ & $(0.22)$ & $(1.06)$ \\
market size & $1.139^{* * *}$ & $1.161^{* * *}$ & $1.197^{* * *}$ & $1.158^{* * *}$ & $2.426^{* * *}$ \\
& $(0.083)$ & $(0.12)$ & $(0.078)$ & $(0.078)$ & $(0.43)$ \\
constant & $-54.47^{* * *}$ & $-59.93^{* * *}$ & $-52.61^{* * *}$ & $-51.52^{* * *}$ & $-106.6^{* * *}$ \\
& $(3.79)$ & $(5.45)$ & $(3.53)$ & $(3.57)$ & $(15.5)$ \\
\hline LR test $\mathrm{H}_{0}: \alpha=0$ & $1.4 \mathrm{e}+06$ & $7.5 \mathrm{e}^{*}+05$ & $6.2 \mathrm{e}+05$ & $5.4 \mathrm{e}+05$ & $7.0 \mathrm{e}^{+0}+04$ \\
& $(0.000)$ & $(0.000)$ & $(0.000)$ & $(0.000)$ & $(0.000)$ \\
Observations & 603 & 526 & 541 & 542 & 577 \\
Log likelihood & -2650 & -1688 & -2321 & -2282 & -303.1 \\
\hline \hline
\end{tabular}

Standard errors in parentheses; * significant at $10 \%$; ** significant at $5 \%$; *** significant at $1 \%$

Table 14: Results with Herfindahl Index as Measure of Institutional Intensity

\section{Appendix}

\section{A. Data Description}

\section{A.1 Intra-firm trade}

The data on intra-firm trade come from the Bureau of Economic Analysis (BEA) surveys of U.S. direct investment abroad. Data are available annually from 1977 to 2004, but the data for benchmark years are more comprehensive. Benchmark surveys (or censuses), are conducted every five years. They cover virtually the entire population of foreign affiliates in terms of dollar value, and they obtain more data items than are collected in the non-benchmark surveys. The BEA conducts sample surveys in the non-benchmark years. These information are reported in the annual time series. Reports are not required for small affiliates in the sample surveys. Instead, BEA estimates the data for these affiliates by extrapolating forward their data from the most recent benchmark survey on 
the basis of the movement of the sample data. Thus, coverage of the affiliate universe is comparable in benchmark and non-benchmark periods. Some data cells are suppressed in order to avoid disclosure of individual firm data. These are treated as missing values. In some other cells data are suppressed, but the value suppressed is known to be between $-\$ 500,000$ and $\$ 500,000$. In this case, I assign a value of $\$ 0$. For a description of these data, see Mataloni (1995).

\subsubsection{A.2 Definitions of Measures of Institutional Intensity}

Nunn's (2007) measure: Rauch classifies goods into three groups: goods traded on an organized exchange (homogeneous goods), reference priced and differentiated products, according to 4-digit SITC Rev. 2 system. I convert this classification into 4-digit 1977 SIC and then to 4-digit 1987 SIC. ${ }^{27}$ I then construct a concordance from the 4-digit 1987 SIC classification to the IO 1992 classification. The 1999 Input-Output table is more aggregated than the 1992 one, and has 69 input industries instead of 496. I aggregate the different input industries in the 1992 IO table in order to make the two comparable. Equal weights are used when aggregating the 1992 IO Use Table to the 1999 IO level. Finally, following Nunn (2007), I construct four measures of the proportion of the intermediate inputs that are relationship-specific:

$$
\begin{gathered}
\text { inst }_{i}^{n c}=\sum_{j} \theta_{i j} R_{j}^{\text {neither_cons }} \\
i n s t_{i}^{n r c}=\sum_{j} \theta_{i j}\left(R_{j}^{\text {neither_cons }}+R_{j}^{\text {ref.priced_cons }}\right) \\
\text { inst }_{i}^{\text {nl }}=\sum_{j} \theta_{i j} R_{j}^{\text {neither_lib }} \\
\text { inst }_{i}^{\text {nrl }}=\sum_{j} \theta_{i j}\left(R_{j}^{\text {neither_lib }}+R_{j}^{\text {ref.priced_lib }}\right)
\end{gathered}
$$

where the first two adopt Rauch's conservative classification, and the following the liberal classification. $\theta_{i j}$ is the ratio of the value of input $j$ in industry $i$ over the total value of all inputs used in industry $i . R_{j}^{\text {neither }}$ is the proportion of input $j$ that is not sold on an organized exchange, nor reference priced, while $R_{j}^{\text {ref. priced }}$ is the proportion of input $j$ that is reference priced. The four

${ }^{27} \mathrm{I}$ use the concordances made available by Jon Haveman at

http://www.macalester.edu/research/economics/page/haveman. 
measures show a Pearson correlation coefficient of 0.99 , significant at $1 \%$ level.

Concentration measures: I compute these indicators using the U.S. InputOutput Table for 1992 and for 1999. All the measures, except entropy and the number of intermediate inputs, increase with concentration. Then, I multiply by -1 the measures, in order to have a set of indexes that increases with the number of inputs, and therefore the number of contracts. These measures are rescaled in order to span the $[0,1]$ interval, with larger values corresponding to higher contract intensity. The measures are defined as follows:

Entropy: $E=-\sum_{i=1}^{n} p_{i} \ln p_{i}$ where $0 \leq H \leq \ln n$ and $p_{i}=\frac{x_{i}}{X}=\frac{x_{i}}{\sum_{i=1}^{n} x_{i}}$

Normalized Entropy: $E_{0}=\frac{E}{E_{\max }}=\frac{E}{\ln E}$ where $E$ is Entropy

Exponential Index: $E X=e^{-H}=\prod_{i=1}^{n} p_{i}^{p_{i}}$

Herfindahl Index: $H=\sum_{i=1}^{n} p_{i}^{2}=\sum_{i=1}^{n} \frac{x_{i}^{2}}{X^{2}}$ where $\frac{1}{n} \leq H \leq 1$

Normalized Herfindahl Index: $H^{*}=\frac{H-\frac{1}{n}}{1-\frac{1}{n}}$ where $0 \leq H^{*} \leq 1$

Gini coefficient: $G=\frac{2}{n^{2} \bar{x}} \sum_{i=1}^{n}\left(\left(i-\frac{n+1}{2}\right) x_{i}\right)$ where $0 \leq G \leq 1$ and $\bar{x}=$ $\frac{1}{n} \sum_{i=1}^{n} x_{i}$

Concentration coefficient: $C=\frac{n}{n-1} G$ where $G$ is the Gini Coefficient

Share of top 10 intermediate inputs: $S=\sum_{i=1}^{10} x_{i}$ where $x_{i}$ are in decreasing order

Number of intermediate inputs: $N=\sum_{x_{i} \neq 0} 1$

\section{A.3 Definitions of Measures of Institutional Quality}

Governance Matters IV Database (Kaufmann et al. 2005) provides six measures of institutional quality. These are indexes that range from -2.5 to 2.5 , with low values corresponding to poor institutional quality. These indicators are based on a huge amount of variables that measure the perception of government quality, which belong to 37 separate data sources, constructed by 31 different organizations. These measures are:

Voice and Accountability: measures the level of political, civil and human rights.

Political Instability and Violence: measures the likelihood of violent threats to, or changes in, government, including terrorism.

Government Effectiveness: measures the competence of the bureaucracy 
and the quality of public service delivery (the quality of public service provision, the quality of the bureaucracy, the competence of civil servants, the independence of civil service from political pressures, and the credibility of the government's commitment to policies).

Regulatory Burden: measures the incidence of market-unfriendly policies, as for example price controls or inadequate bank supervision, as well as perceptions of the burdens imposed by excessive regulation in areas such as foreign trade and business development.

Rule of Law: measures the quality of contract enforcement, police, and courts, as well as the likelihood of crime and violence. This is our preferred variable as it refers specifically to the quality of contract enforcement.

Control of Corruption: measures the exercise of public power for private gain, including both petty and grand corruption and state capture.

\section{B. Country List}

The countries included in the analysis are: Argentina, Australia, Austria, Bahamas, Barbados, Belgium, Bermuda, Brazil, Canada, Chile, China, Colombia, Costa Rica, Czech Republic, Denmark, Dominican Republic, Ecuador, Egypt, Finland, France, Germany, Greece, Guatemala, Honduras, Hong Kong, Hungary, India, Indonesia, Ireland, Israel, Italy, Jamaica, Japan, Republic of Korea, Luxembourg, Malaysia, Mexico, Netherlands, Netherlands Antilles, New Zealand, Nigeria, Norway, Panama, Peru, Philippines, Poland, Portugal, Russia, Saudi Arabia, Singapore, South Africa, Spain, Sweden, Switzerland, Tai-

wan, Thailand, Trinidad and Tobago, Turkey, United Arab Emirates, United Kingdom, United Kingdom Islands Caribbean,Venezuela. 


\section{CESifo Working Paper Series}

for full list see www.cesifo-group.org/wp

(address: Poschingerstr. 5, 81679 Munich, Germany, office@cesifo.de)

2008 Mikael Priks, Judiciaries in Corrupt Societies, June 2007

2009 Steinar Holden and Fredrik Wulfsberg, Downward Nominal Wage Rigidity in the OECD, June 2007

2010 Emmanuel Dhyne, Catherine Fuss, Hashem Pesaran and Patrick Sevestre, Lumpy Price Adjustments: A Microeconometric Analysis, June 2007

2011 Paul Belleflamme and Eric Toulemonde, Negative Intra-Group Externalities in TwoSided Markets, June 2007

2012 Carlos Alós-Ferrer, Georg Kirchsteiger and Markus Walzl, On the Evolution of Market Institutions: The Platform Design Paradox, June 2007

2013 Axel Dreher and Martin Gassebner, Greasing the Wheels of Entrepreneurship? The Impact of Regulations and Corruption on Firm Entry, June 2007

2014 Dominique Demougin and Claude Fluet, Rules of Proof, Courts, and Incentives, June 2007

2015 Stefan Lachenmaier and Horst Rottmann, Effects of Innovation on Employment: A Dynamic Panel Analysis, June 2007

2016 Torsten Persson and Guido Tabellini, The Growth Effect of Democracy: Is it Heterogenous and how can it be Estimated?, June 2007

2017 Lorenz Blume, Jens Müller, Stefan Voigt and Carsten Wolf, The Economic Effects of Constitutions: Replicating - and Extending - Persson and Tabellini, June 2007

2018 Hartmut Egger and Gabriel Felbermayr, Endogenous Skill Formation and the Source Country Effects of International Labor Market Integration, June 2007

2019 Bruno Frey, Overprotected Politicians, June 2007

2020 Jan Thomas Martini, Rainer Niemann and Dirk Simons, Transfer Pricing or Formula Apportionment? Tax-Induced Distortions of Multinationals' Investment and Production Decisions, June 2007

2021 Andreas Bühn, Alexander Karmann and Friedrich Schneider, Size and Development of the Shadow Economy and of Do-it-yourself Activities in Germany, June 2007

2022 Michael Rauscher and Edward B. Barbier, Biodiversity and Geography, June 2007

2023 Gunther Schnabl, Exchange Rate Volatility and Growth in Emerging Europe and East Asia, June 2007 
2024 Erkki Koskela and Ronnie Schöb, Tax Progression under Collective Wage Bargaining and Individual Effort Determination, June 2007

2025 Jay Pil Choi and Marcel Thum, The Economics of Politically Connected Firms, June 2007

2026 Jukka Pirttilä and Roope Uusitalo, Leaky Bucket in the Real World: Estimating Inequality Aversion Using Survey Data, June 2007

2027 Ruslan Lukach, Peter M. Kort and Joseph Plasmans, Strategic R\&D with Knowledge Spillovers and Endogenous Time to Complete, June 2007

2028 Jarko Fidrmuc, Neil Foster and Johann Scharler, Labour Market Rigidities, Financial Integration and International Risk Sharing in the OECD, June 2007

2029 Bernardina Algieri and Thierry Bracke, Patterns of Current Account Adjustment Insights from Past Experience, June 2007

2030 Robert Dur and Hein Roelfsema, Social Exchange and Common Agency in Organizations, June 2007

2031 Alexander Libman and Lars P. Feld, Strategic Tax Collection and Fiscal Decentralisation: The Case of Russia, June 2007

2032 Øystein Foros, Hans Jarle Kind and Greg Shaffer, Resale Price Maintenance and Restrictions on Dominant Firm and Industry-Wide Adoption, June 2007

2033 Jan K. Brueckner and Kurt Van Dender, Atomistic Congestion Tolls at Concentrated Airports? Seeking a Unified View in the Internalization Debate, June 2007

2034 Viet Do and Ngo Van Long, International Outsourcing under Monopolistic Competition: Winners and Losers, June 2007

2035 Nadia Fiorino and Roberto Ricciuti, Determinants of Direct Democracy, June 2007

2036 Burkhard Heer and Alfred Maussner, Inflation and Output Dynamics in a Model with Labor Market Search and Capital Accumulation, June 2007

2037 Konstantinos Angelopoulos, Jim Malley and Apostolis Philippopoulos, Public Education Expenditure, Growth and Welfare, June 2007

2038 Maarten Bosker, Steven Brakman, Harry Garretsen and Marc Schramm, Adding Geography to the New Economic Geography, June 2007

2039 Steffen Henzel, Oliver Hülsewig, Eric Mayer and Timo Wollmershäuser, The Price Puzzle Revisited: Can the Cost Channel Explain a Rise in Inflation after a Monetary Policy Shock?, July 2007

2040 Rosario Crinò, Service Offshoring and White-Collar Employment, July 2007 
2041 Carsten Hefeker and Michael Neugart, Labor Market Regulation and the Legal System, July 2007

2042 Bart Cockx and Muriel Dejemeppe, Is the Notification of Monitoring a Threat to the Unemployed? A Regression Discontinuity Approach, July 2007

2043 Alfons J. Weichenrieder, Profit Shifting in the EU: Evidence from Germany, July 2007

2044 Annika Alexius and Bertil Holmlund, Monetary Policy and Swedish Unemployment Fluctuations, July 2007

2045 Axel Dreher, Jan-Egbert Sturm and Jakob de Haan, Does High Inflation Cause Central Bankers to Lose their Job? Evidence Based on a New Data Set, July 2007

2046 Guglielmo Maria Caporale and Luis A. Gil-Alana, Long Run and Cyclical Dynamics in the US Stock Market, July 2007

2047 Alessandro Balestrino, It is a Theft but not a Crime, July 2007

2048 Daniel Becker and Michael Rauscher, Fiscal Competition in Space and Time: An Endogenous-Growth Approach, July 2007

2049 Yannis M. Ioannides, Henry G. Overman, Esteban Rossi-Hansberg and Kurt Schmidheiny, The Effect of Information and Communication Technologies on Urban Structure, July 2007

2050 Hans-Werner Sinn, Please bring me the New York Times - On the European Roots of Richard Abel Musgrave, July 2007

2051 Gunther Schnabl and Christian Danne, A Role Model for China? Exchange Rate Flexibility and Monetary Policy in Japan, July 2007

2052 Joseph Plasmans, Jorge Fornero and Tomasz Michalak, A Microfounded Sectoral Model for Open Economies, July 2007

2053 Vesa Kanniainen and Panu Poutvaara, Imperfect Transmission of Tacit Knowledge and other Barriers to Entrepreneurship, July 2007

2054 Marko Koethenbuerger, Federal Tax-Transfer Policy and Intergovernmental PreCommitment, July 2007

2055 Hendrik Jürges and Kerstin Schneider, What Can Go Wrong Will Go Wrong: Birthday Effects and Early Tracking in the German School System, July 2007

2056 Bahram Pesaran and M. Hashem Pesaran, Modelling Volatilities and Conditional Correlations in Futures Markets with a Multivariate t Distribution, July 2007

2057 Walter H. Fisher and Christian Keuschnigg, Pension Reform and Labor Market Incentives, July 2007 
2058 Martin Altemeyer-Bartscher, Dirk T. G. Rübbelke and Eytan Sheshinski, Policies to Internalize Reciprocal International Spillovers, July 2007

2059 Kurt R. Brekke, Astrid L. Grasdal and Tor Helge Holmås, Regulation and Pricing of Pharmaceuticals: Reference Pricing or Price Cap Regulation?, July 2007

2060 Tigran Poghosyan and Jakob de Haan, Interest Rate Linkages in EMU Countries: A Rolling Threshold Vector Error-Correction Approach, July 2007

2061 Robert Dur and Klaas Staal, Local Public Good Provision, Municipal Consolidation, and National Transfers, July 2007

2062 Helge Berger and Anika Holler, What Determines Fiscal Policy? Evidence from German States, July 2007

2063 Ernesto Reuben and Arno Riedl, Public Goods Provision and Sanctioning in Privileged Groups, July 2007

2064 Jan Hanousek, Dana Hajkova and Randall K. Filer, A Rise by Any Other Name? Sensitivity of Growth Regressions to Data Source, July 2007

2065 Yin-Wong Cheung and Xing Wang Qian, Hoarding of International Reserves: Mrs Machlup's Wardrobe and the Joneses, July 2007

2066 Sheilagh Ogilvie, 'Whatever Is, Is Right'?, Economic Institutions in Pre-Industrial Europe (Tawney Lecture 2006), August 2007

2067 Floriana Cerniglia and Laura Pagani, The European Union and the Member States: Which Level of Government Should Do what? An Empirical Analysis of Europeans' Preferences, August 2007

2068 Alessandro Balestrino and Cinzia Ciardi, Social Norms, Cognitive Dissonance and the Timing of Marriage, August 2007

2069 Massimo Bordignon, Exit and Voice. Yardstick versus Fiscal Competition across Governments, August 2007

2070 Emily Blanchard and Gerald Willmann, Political Stasis or Protectionist Rut? Policy Mechanisms for Trade Reform in a Democracy, August 2007

2071 Maarten Bosker and Harry Garretsen, Trade Costs, Market Access and Economic Geography: Why the Empirical Specification of Trade Costs Matters, August 2007

2072 Marco Runkel and Guttorm Schjelderup, The Choice of Apportionment Factors under Formula Apportionment, August 2007

2073 Jay Pil Choi, Tying in Two-Sided Markets with Multi-Homing, August 2007

2074 Marcella Nicolini, Institutions and Offshoring Decision, August 2007 